\title{
The Re-evaluation of Kerman Neolithic Chronology Based on the Excavation of Tepe Gav Koshi Esfandagheh- Jiroft
}

\author{
Nader Alidadi Soleimani ${ }^{\star 1}$, Hassan Fazeli Nashli ${ }^{2}$ \\ ${ }^{1}$ Ph.D. in Archaeology, University of Tehran, Tehran, IRAN \\ ${ }^{2}$ Professor, Department of Archaeology, University of Tehran, Tehran, IRAN
}

Received: 03/11/2018

Accepted: 29/12/2018

\begin{abstract}
Recently, three season of archeological investigation on the Esfandagheh plain in Kerman province has been carried and several Neolithic sites back to seven and six millennium BC has been recorded in this region. Among these, Gav Koshi is a small Neolithic site less than one hectares and has been located in the northwest city of Jiroft. Based on the results of three season of excavations, the site has two important ceramic Neolithic phase of early seventh (with more than 500 years of occupation) and late seventh millennium BC with some gaps between on it. In recent chronological study, Khanipour and Niknami (2017) propose the following chronological tables for the Fars regions includes Transitional Rahmat Abad (7500-7000 BC), Formative Mushki (7000-6400 BC), Mushki (6400-6000 BC), Jari (60005600 BC) and Shams Abad (5600-5200 BC) and therefore, the first phase of Gav Koshi back to the Formative Gav Koshi (700-6500 BC) with local development. While the site abandoned for a short period of time, it was reoccupied again during the Gav koshi period (ca. 6400-6000 BC, see table 1). The ceramics of the first phase is completely local and handmade with a fine greyish slip covered on the surface. The red geometric broken lines applied on the exterior around the neck of bowls or diamond used the entire of surface???. The houses were made with mudbrick structures $(35 \times 12 \times 12$ $\mathrm{cm}$ ), sometimes the thickness of mudbrick is $50 \mathrm{~cm}$, and so three mudbrick contains the thickness of wall, where they have been usually joint to each other. The houses dimensions were usually between $2.50 \mathrm{~m}$ to $4 \mathrm{~m}$, indicates enough space for each family. Usually, the floor was covered by red ochre. For the roof, they usually used local reed which is still grow in the region. One of the important discovery of Gav Koshi was a room with dimensions of $285 \times 360 \mathrm{~cm}$, with a floor raised look like a platform and the floor carefully painted with red ochre. The whole internal walls were also painted with red ochre. Numerous of animal bones and also lots of human and animal figuries were found inside the room, indicates that the room had been probably used for ritual practices. The second phase was very close to the surface and it seems by the time the archtectural remains have been destroyed. While the ceramic of the lower layers indicates local development, but chronologically, the ceramics of upper layers reveal regional chrecterestics similar with Kushk-e Hezar, Mushki/Bashi, Qasr e-Ahmad and Harmangan in the Fars region (Khanipour and Niknami, 2017). During the second phase of Gav Koshi, several samples of mortars and pestles found with the obsidian cores and blades, all indicates regionalization of Kerman Neolithic during the last quarter of seven millennium BC.
\end{abstract}

Keywords: Gav Koshi, Southern Iran, Kerman, Jiroft, Neolithic, Radiocarbon Absolute dating 


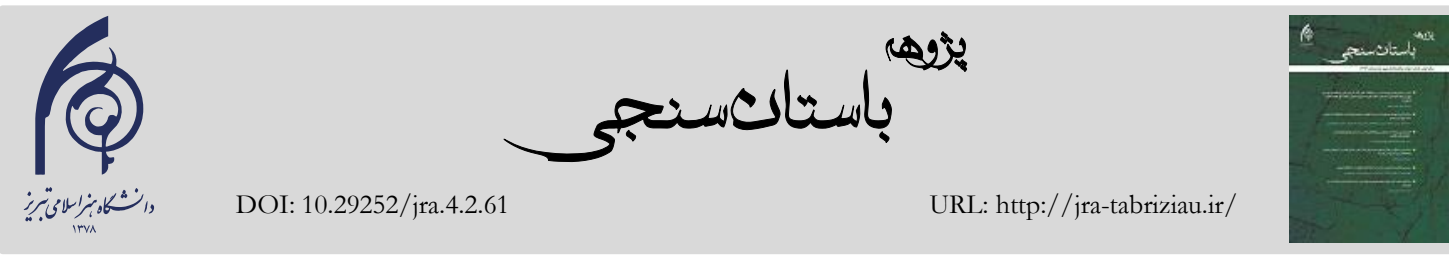

sقالم يَّوهشى
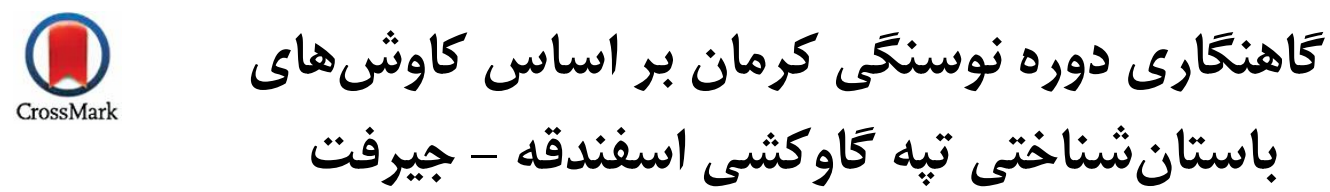

نادر عليدادى سليمانى "'، حسن فاضلى نشلى

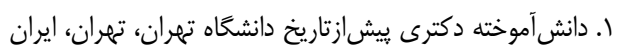

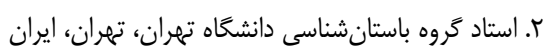

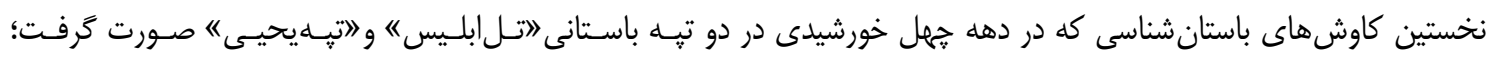

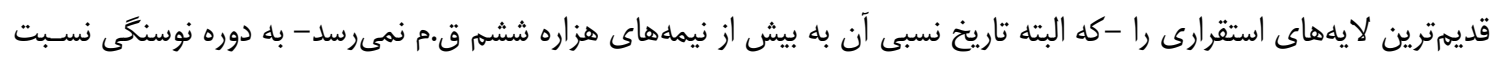

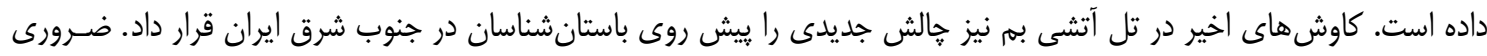

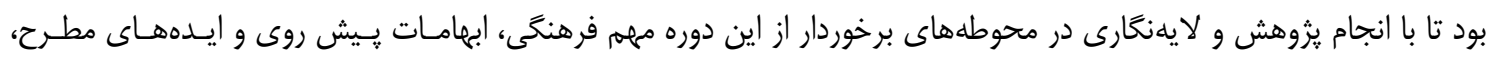

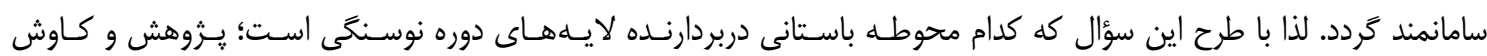

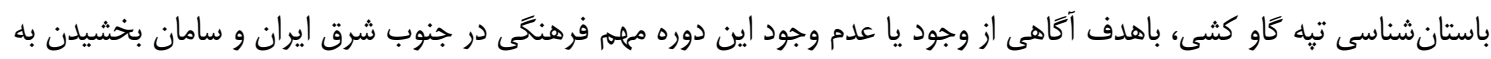

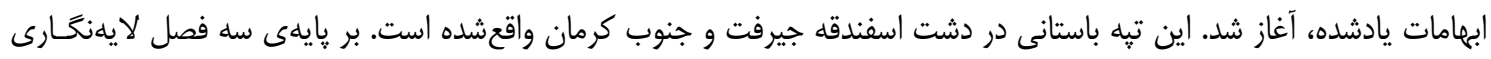

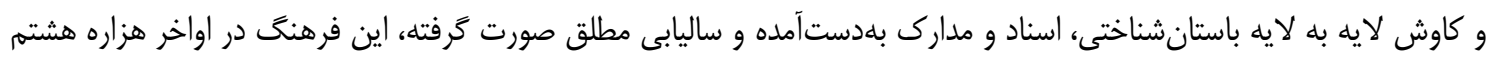

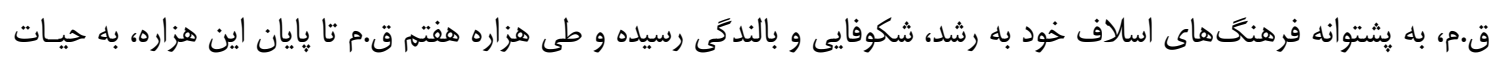

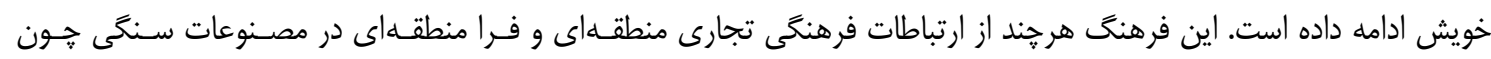

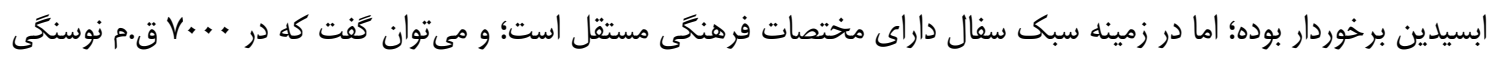

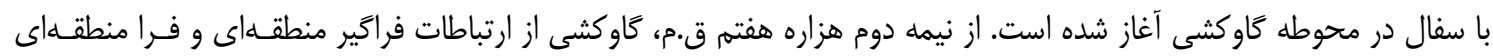

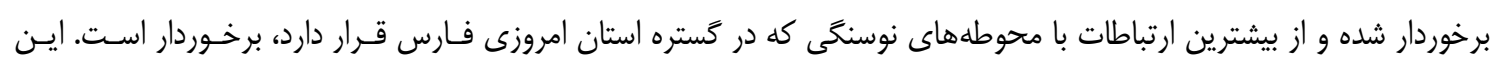

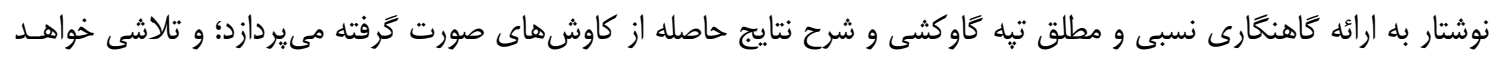

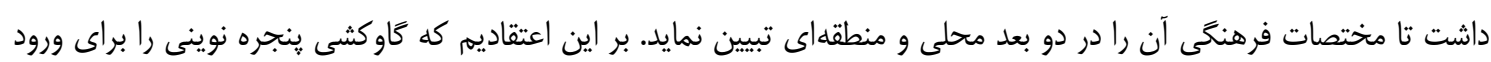
به اين دوران در منطقه كرمان كَّوده است.

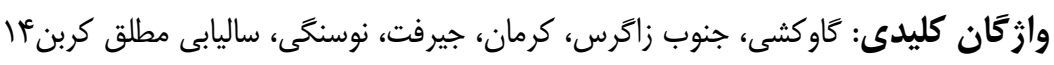

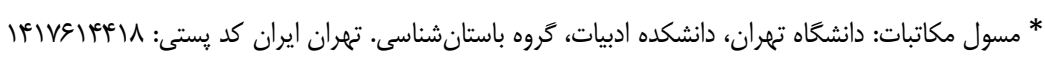

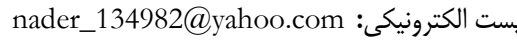

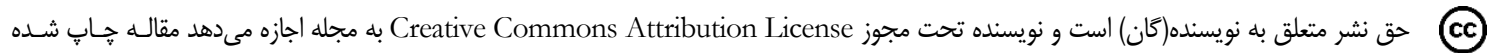
را با ديخران به اشتراى بخذارد منوط بر اينكه حقوق مؤلف اثر حفظ و به انتشار اوليه مقاله در اين مجله اشاره شود. 
مى كنند و يا اينكه نوسنگى شدن آن ييامد تغييرات جنوب

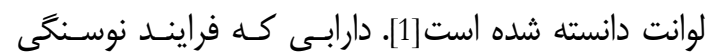
شدن زاترس مركزى را در بوته ارزيابى مجـدد قـرار داده

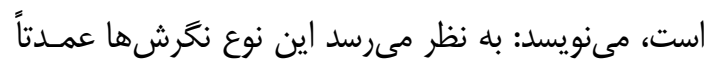

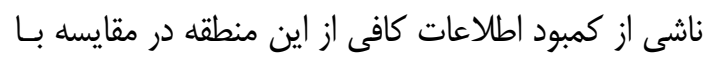

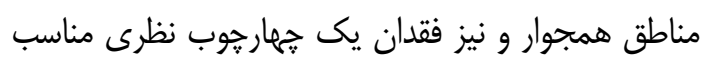

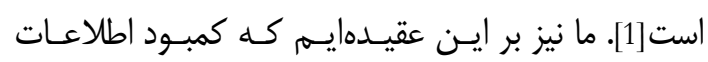

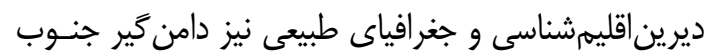

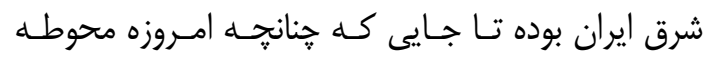

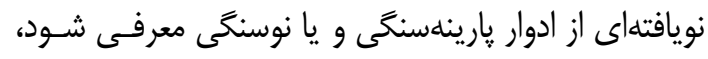

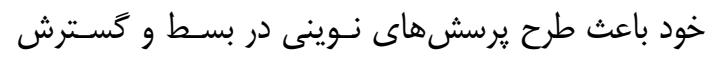

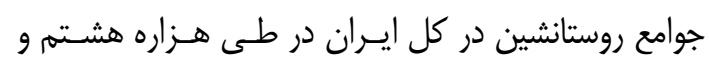

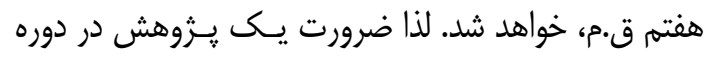

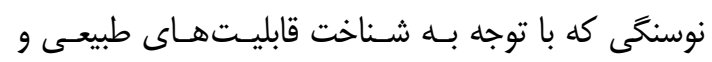
اكولوزيكى كه در منطقه وجود داشت و با طرح اين سـؤه بـال

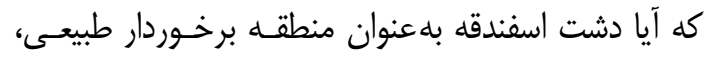
دربردارنده استقرارهاى دوره موردنظر ما هست، ابتدا طــرح

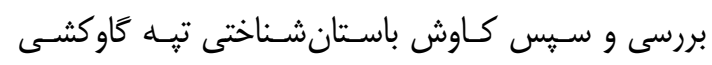

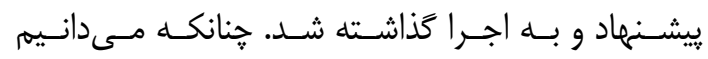

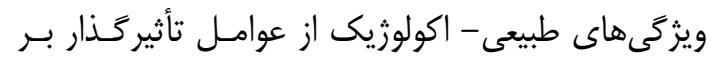

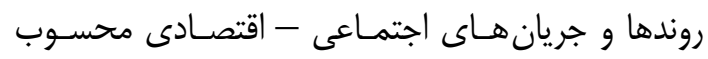

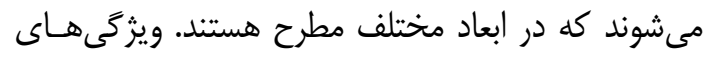

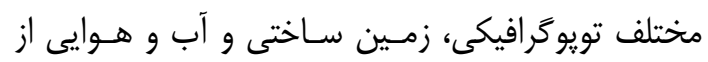

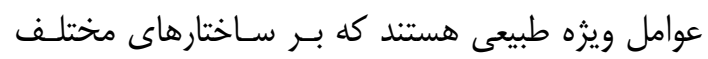

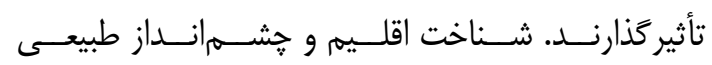

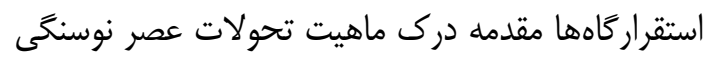

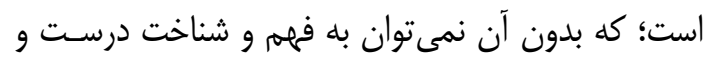
دقيق از اسباب و دلايل يبيدايش روستانشـينى و اقتصـاد

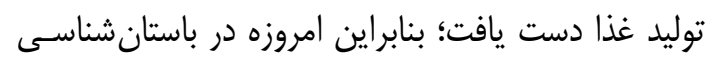
عصر نوسنگى، بالأخص مبحث نوسنكى شدن، مطالعات

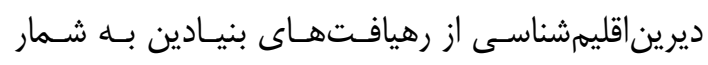

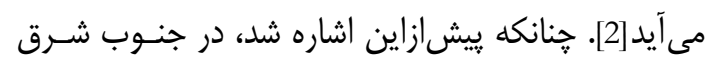

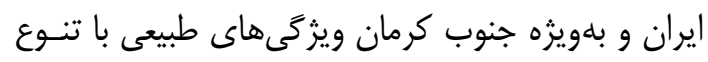

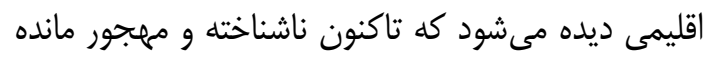

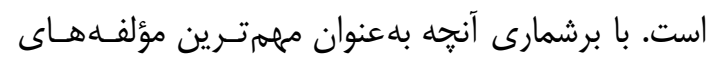

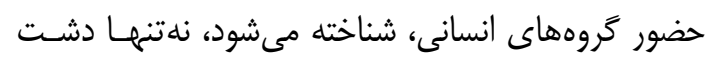

(. - مقدمه

جنوب شرق ايران و بلهويـزه گَسـتره اسـتان كرمـان كـهـ

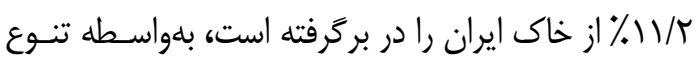

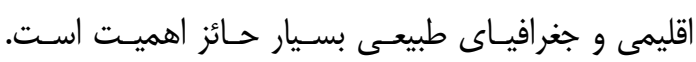

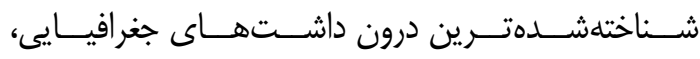

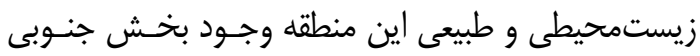

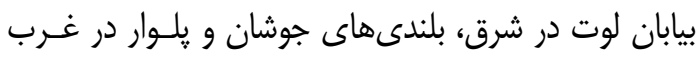

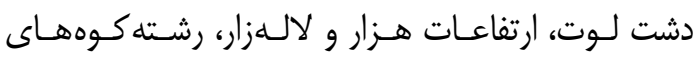

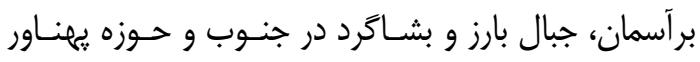

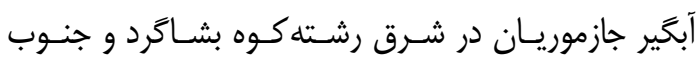

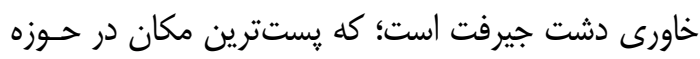

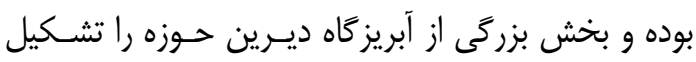

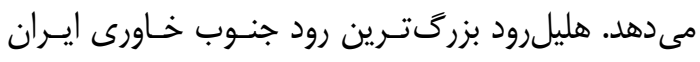

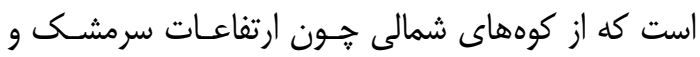

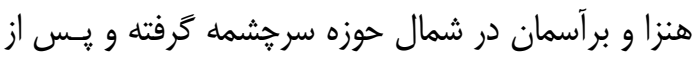

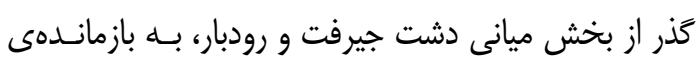

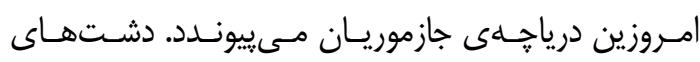

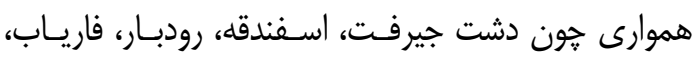

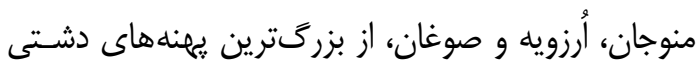

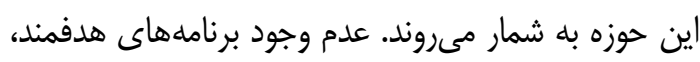

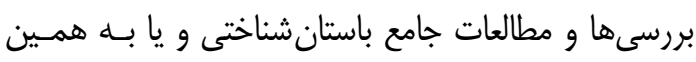

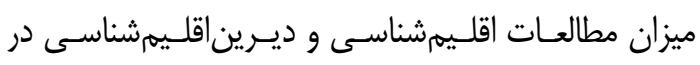

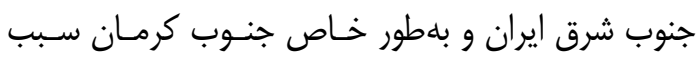

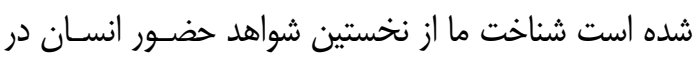

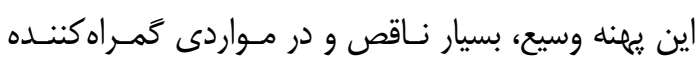

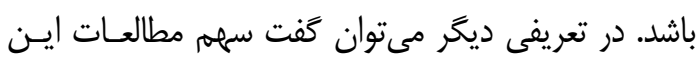

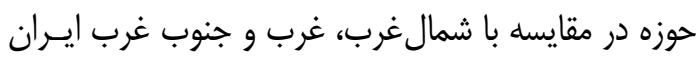

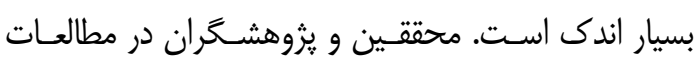

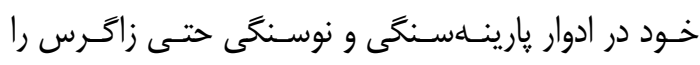

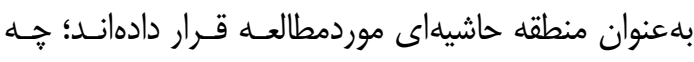

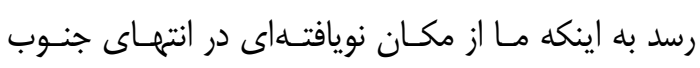

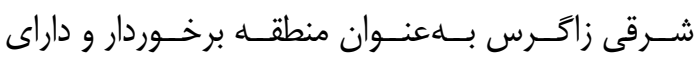

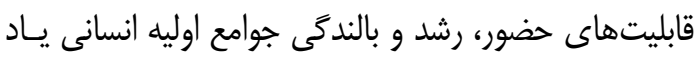

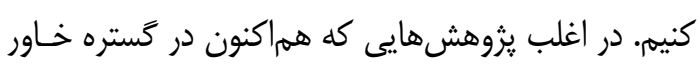

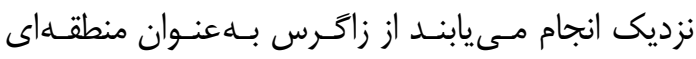

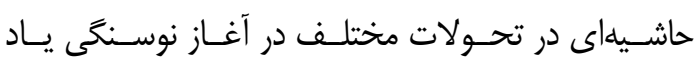


فرهنگى اين محوطه و شرح و تفسير نتايج ساليابى كربن

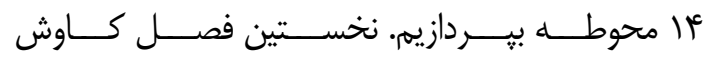

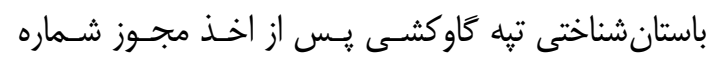

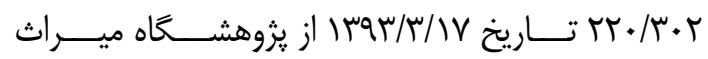

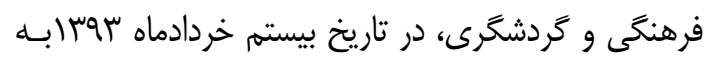

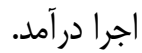

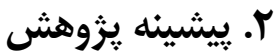

ئروهش هاى باستانشناسى جنوب شرق ايران، در مقايسـهـ

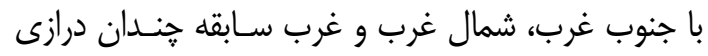

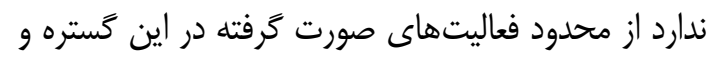
بلهويزه استان كرمان، كه به مطالعات يـيش از دوره مس فـ سنگ يرداخته است، بسيار محدود و ناجيز است، شناسايى

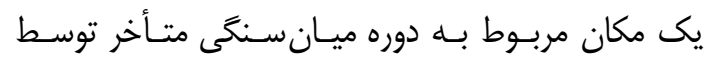

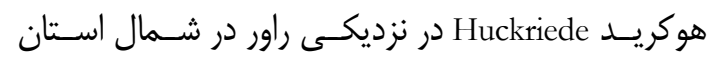

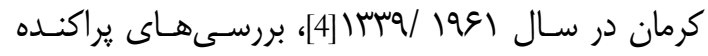

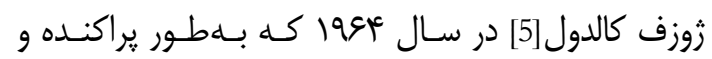

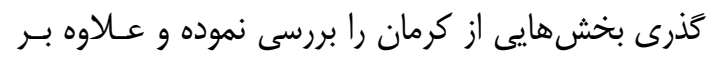

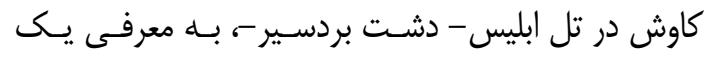

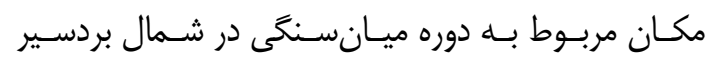

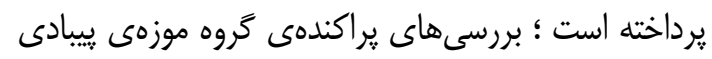

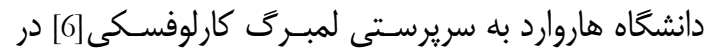

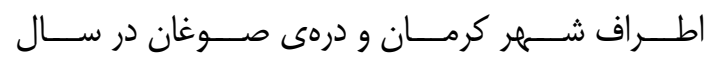

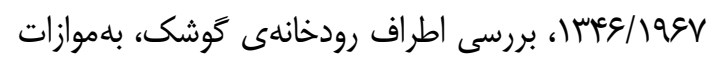

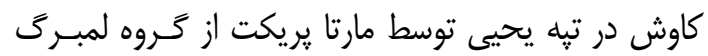

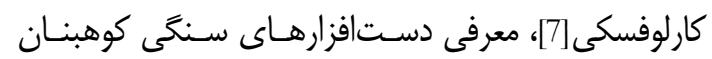

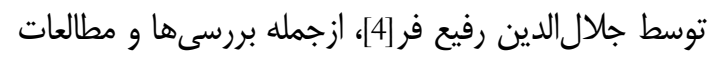

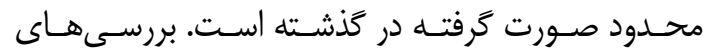

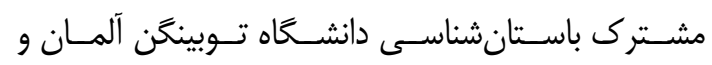

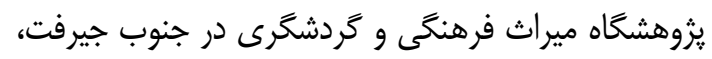

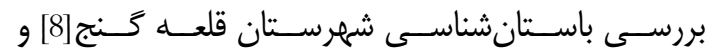

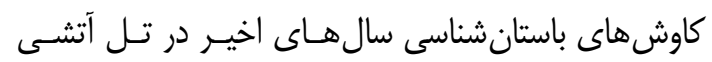

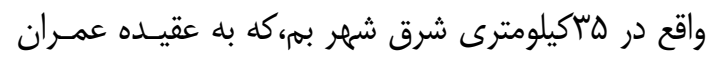

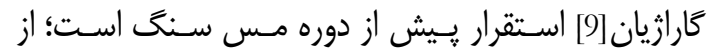

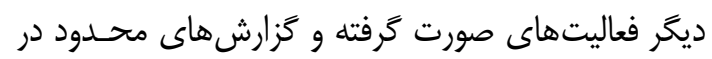

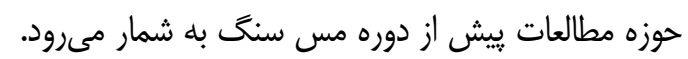

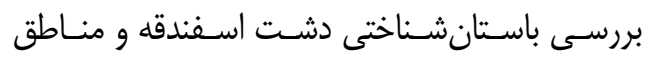

اسفندقه بلكه كستره وسيعى از اين حوضه جغرافيايى كه

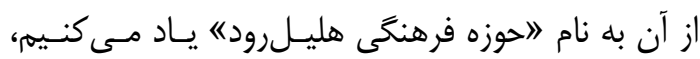

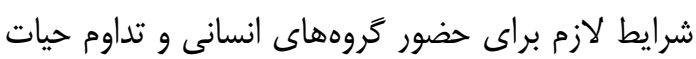

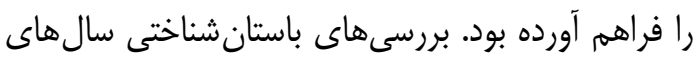

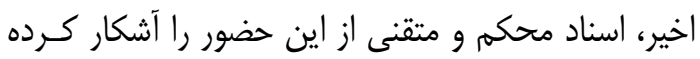
افزون بر تبه كاوكشى، اسناد و مدارك درخور توجهى

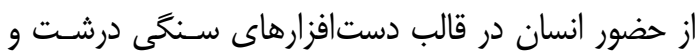

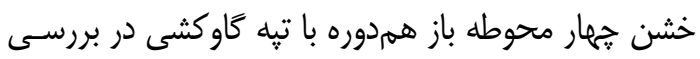

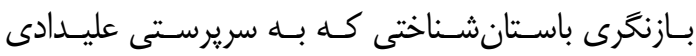

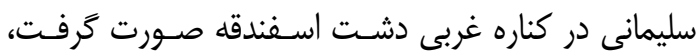

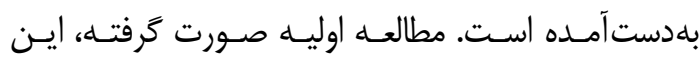
دستافزارها را بر پايه فرم و مشخصات ظـاهرى بـهـ دوره

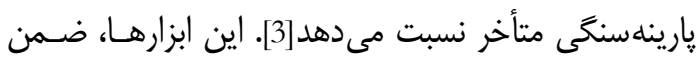

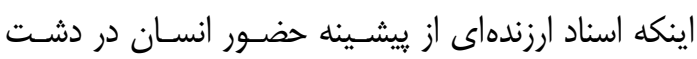
اسفندقه و مناطق ييرامون با اقليم مشابه را ييش روى مـا قرار مىدهد، شواهد محكمى است؛ كه حضـور انسـان در

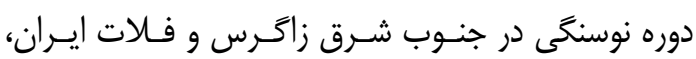

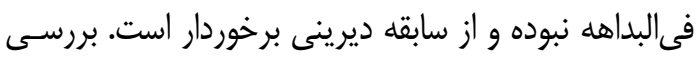

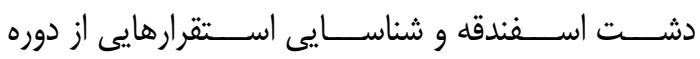

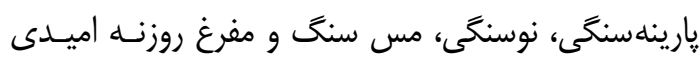

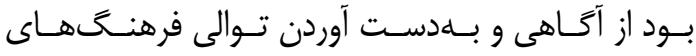

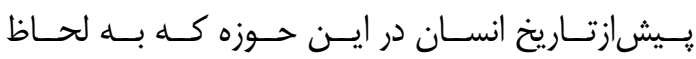

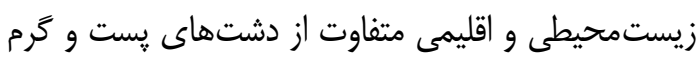

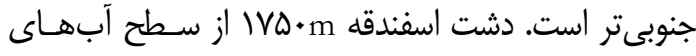

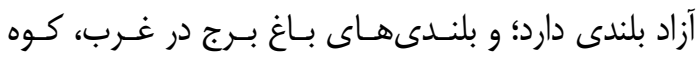
قرقوتويه در شمال و كوه شيخ يعقوب در شرق بــه همـراه

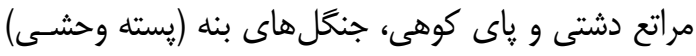

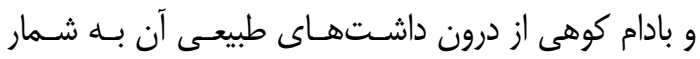

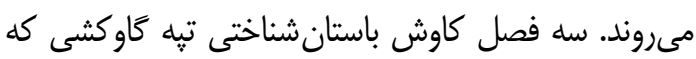

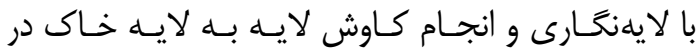
بخشهاى مختلف تبه و در قالـب ترانشـهـهـاى بــا ابعـاد

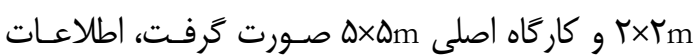

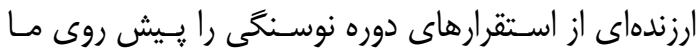

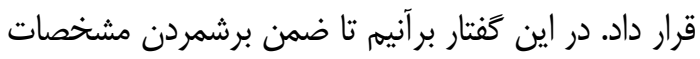

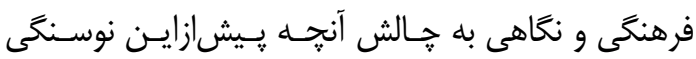

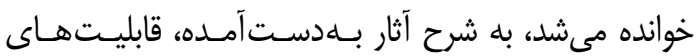




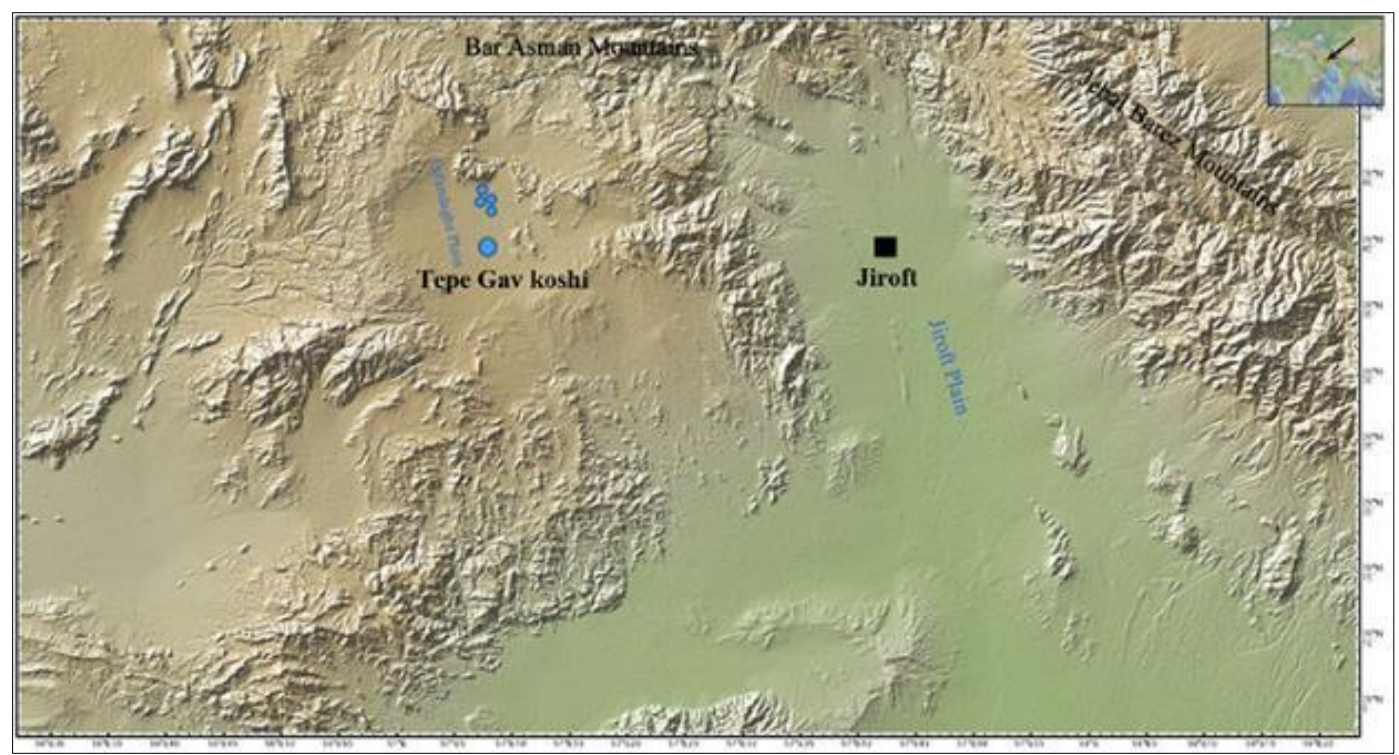

شكل ا : موقعيت تبه كاوكشى در نقشه ايران

Fig 1: The Location of the Gav koshi in Iran Map

يكى از دشتهاى ميان كوهى در حوضـهى آبريـز هليـل

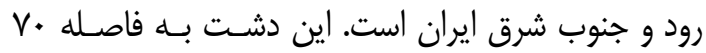
كيلومترى شمال باخترى شهر جيرفت قرار دارد (شكل ().

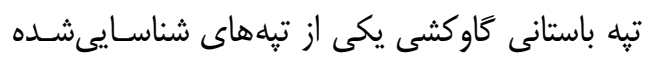

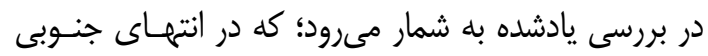

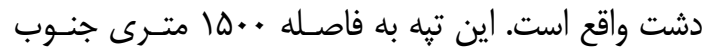

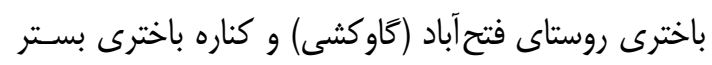

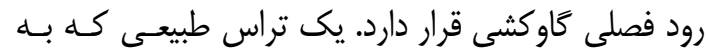

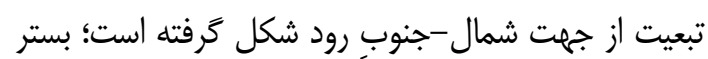

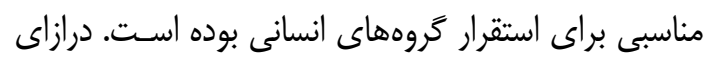

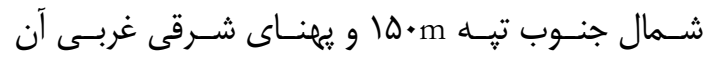

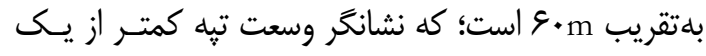

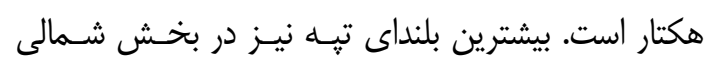

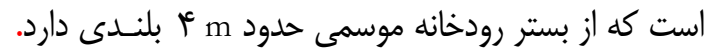

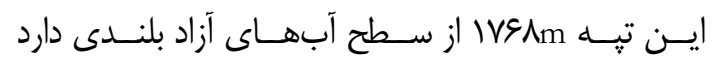

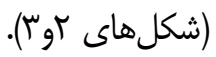
گروه باستان شناسـى هـيش ازتـاريخ دشـت اسـفندقه

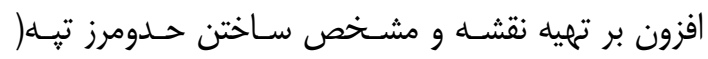

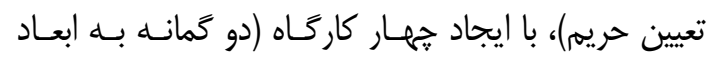

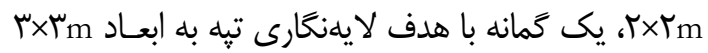

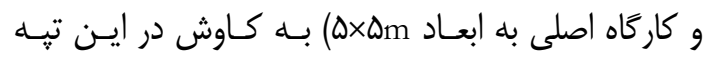

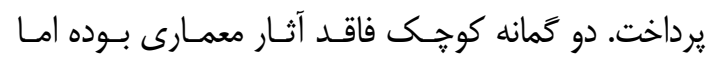

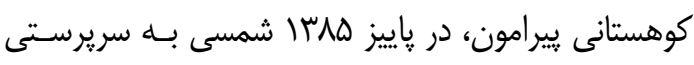
يكى از نغارندكان اين مقاله (عليدادى سليمانى) به انجـام

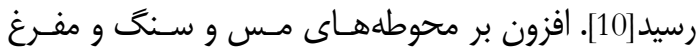

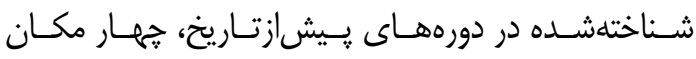

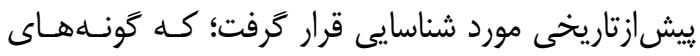

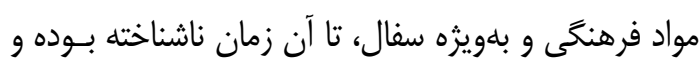

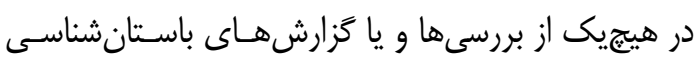
ارائهشده در كستره استان كرمان ديده نشده است. حضـور

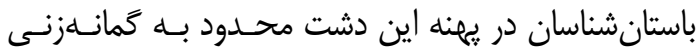

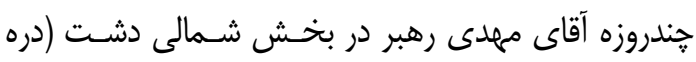
كنارويه) و كاوش در يك گورستان عصر مفرغ بـود. نظـر

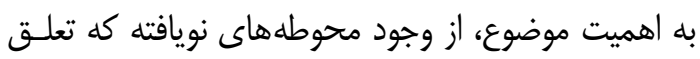

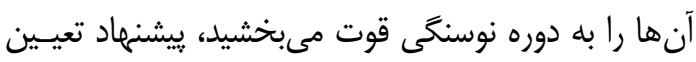
عرصه، حريم و كاوش باستانشناختى تبه كاوكشى -كسئ

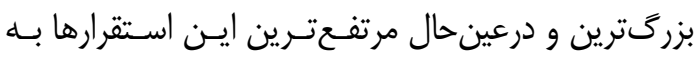
شمار مىرفت- به يثوهشكده باستان شناسى ارائه و مجــوز لازم اخذ كرديد.

\section{". مواد فرهنَّى و روش كاوش

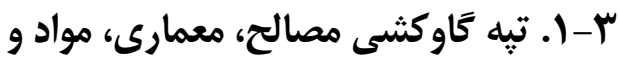 روشها} دشت اسفندقه بـا كَسـترهاى بـيش از

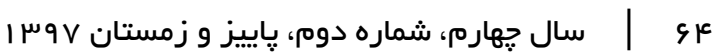




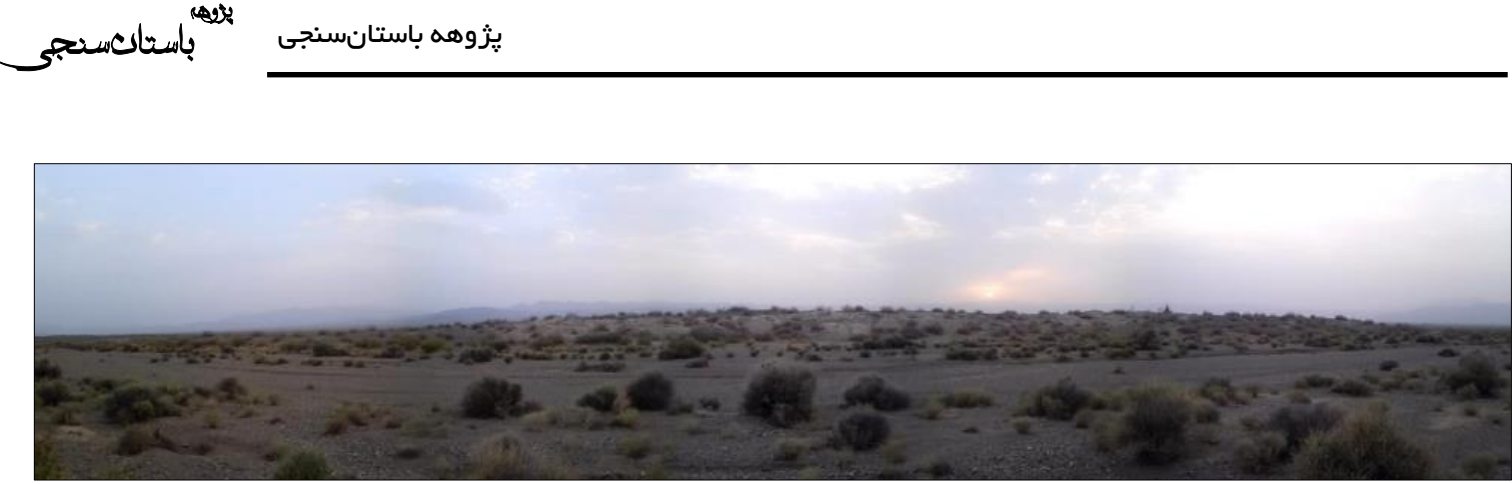

شكل r: نماى عمومى تبه گاوكشى - ديد از شرق

Fig. 2: General view of the Tepe Gav koshi -view from East
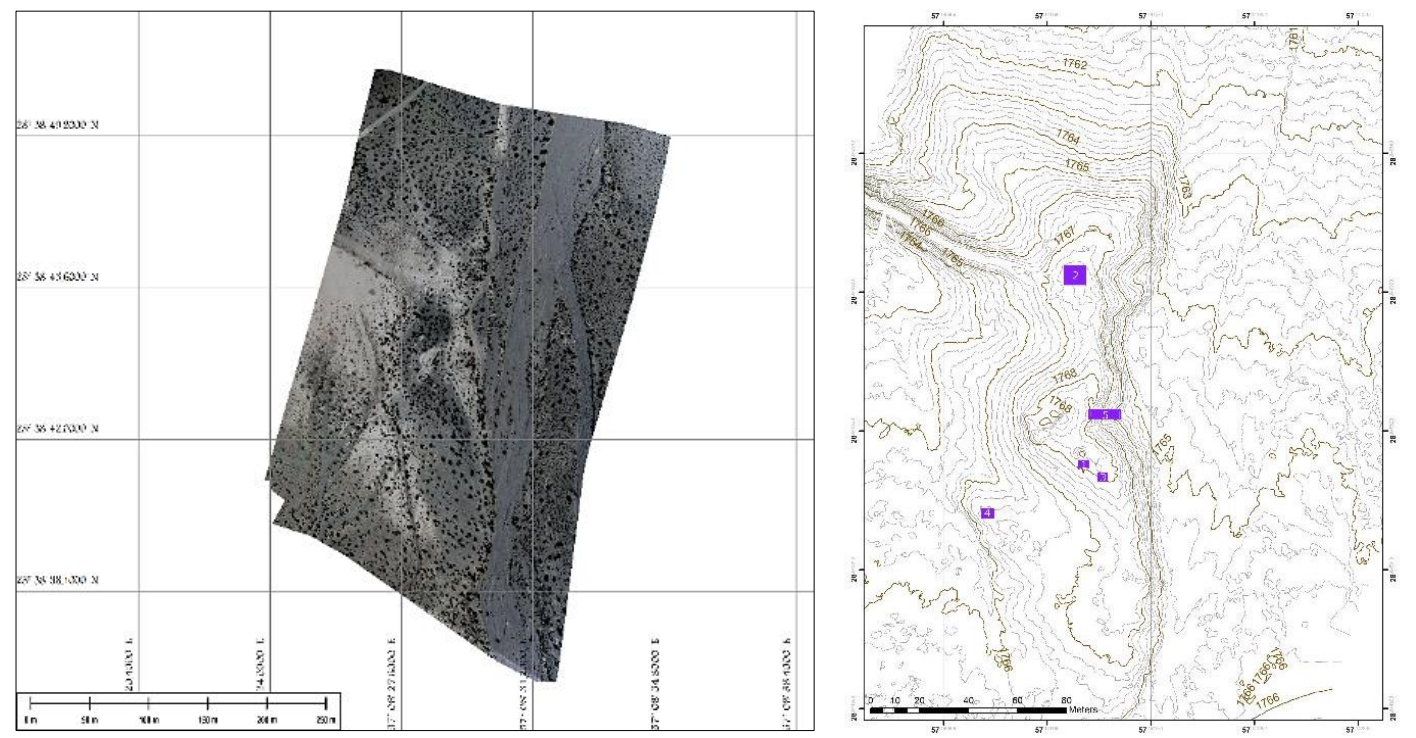

شكل "ا: نقشه تويوكر افى و تصوير هوايى تيه كاو كشى و موقعيت ترانشهاى ايجاد شده

Fig. 3: Picture and Topographic map of Tepe Gav koshi and the excavated areas

داشت. در كاوش تيه كاوكشى با هدف ايجاد نظهم در فهـم

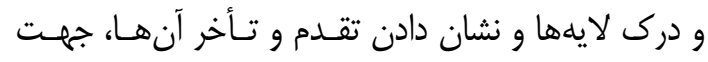

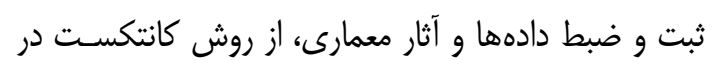

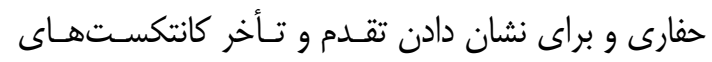
مختلف از نمـودار هـريس[11] اسـتفاده شـده اسـت. آثـار معمارى با شماره ساختار (فيجر: Feature) و ساير پيديدههــا

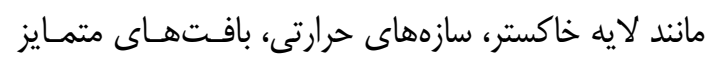

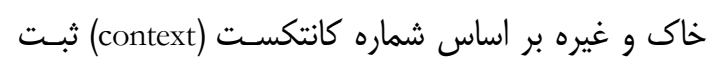
شدهاند. براى ثبت دقيق عمق يافتهها، عمق هـــ يافتـــ از

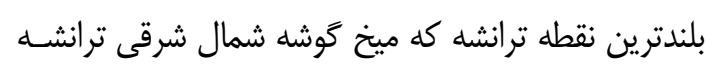
بود، سنجيده مىشد.

\section{fأ فاز نخست (دوره شكل تَيرى كاوكشى)} با برداشت لايه به لايه خاك، نخستين شواهد تُو معمارى
يافتهام فرهنكى آن كه اغلب در قالب سفال ديده مى دشد

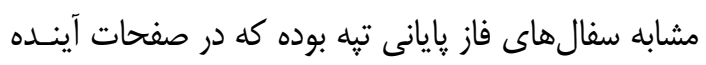

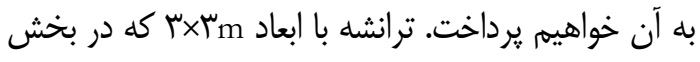

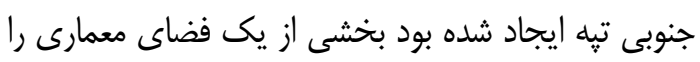

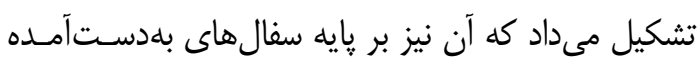

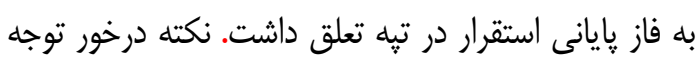

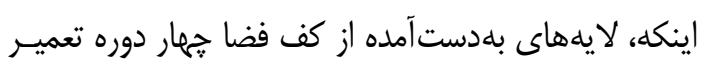

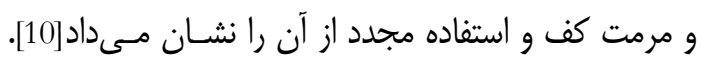

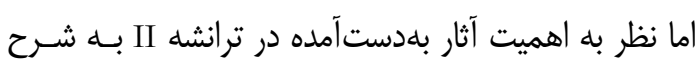

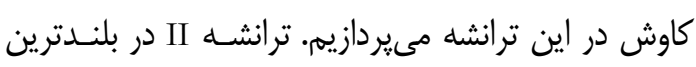

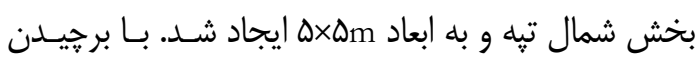

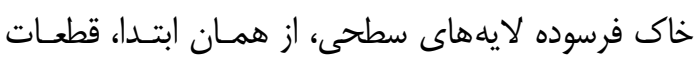

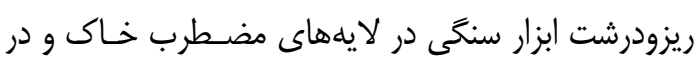

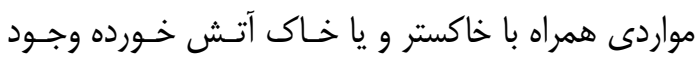

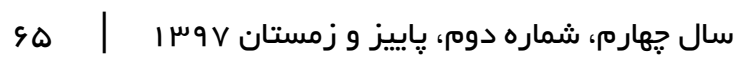



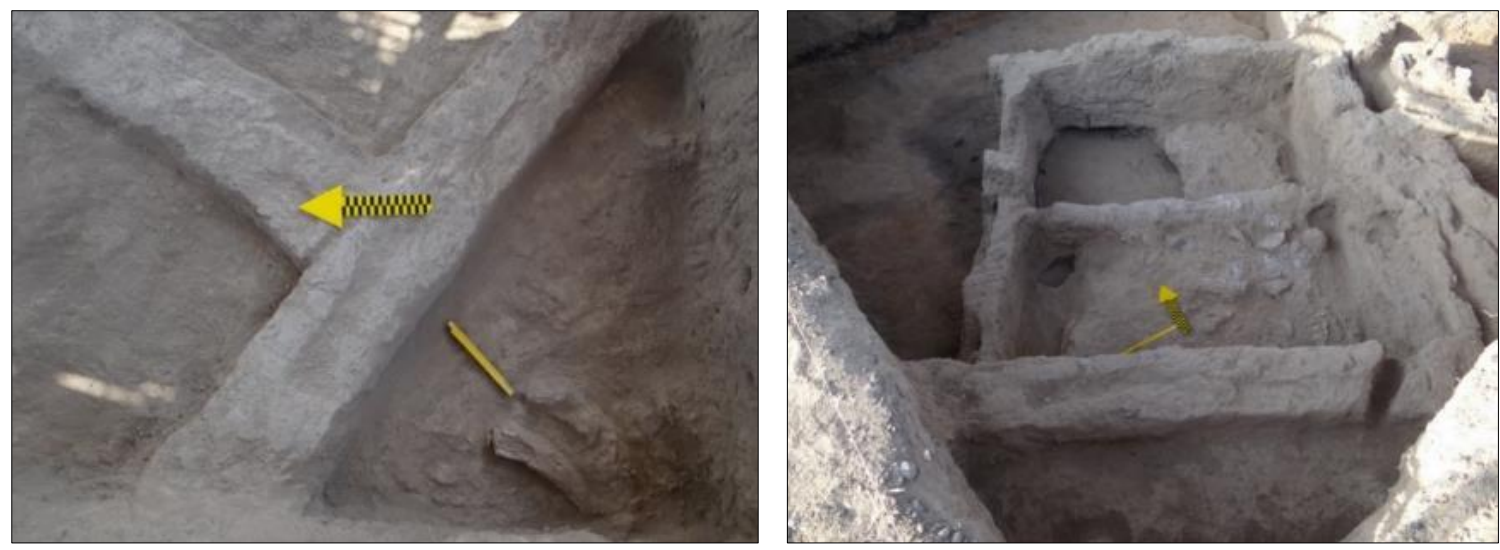

شكلهاى f: معمارى نوسنكى كاوكشى (فاز قديم)

Fig. 4: The Neolithic architecture of Gav koshi (old phase)

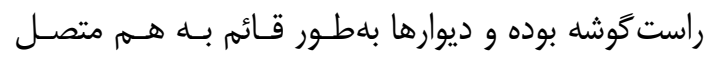

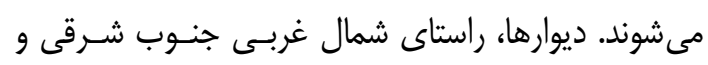

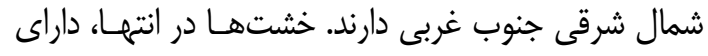

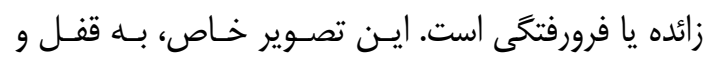

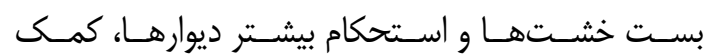

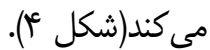
در بخش هاى مختلـف بـرش و بـهـويـزه در فضـاى

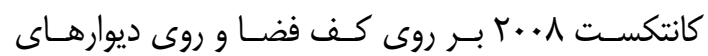

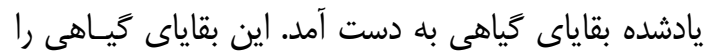

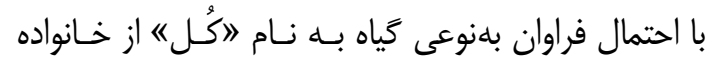

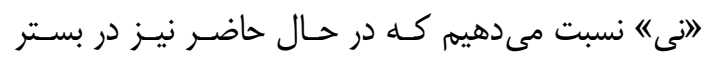

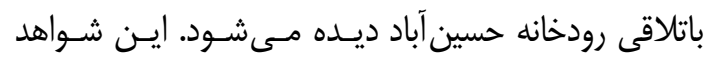

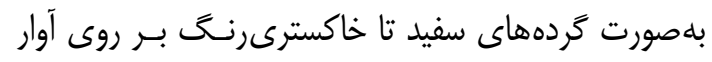

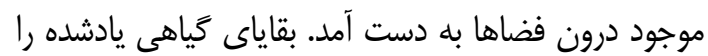
بلعنوان شـواهد موجـود از نـوع يوشـش سـقـف اتـاقهــا

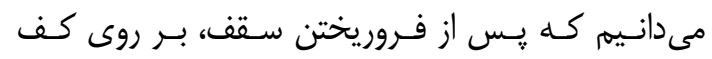

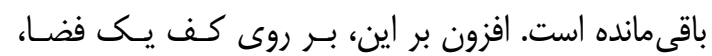

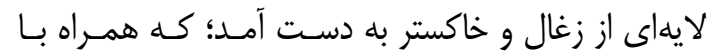

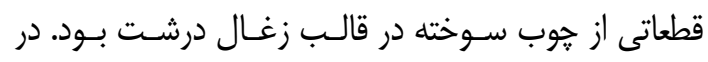

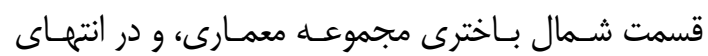

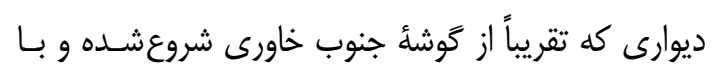

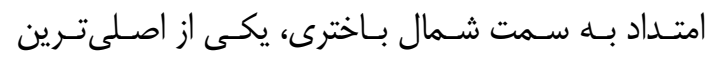
ديوارهاى مجموعه را تشكيل مى دهد، در بخـش خـارجى إنى

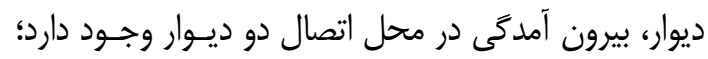

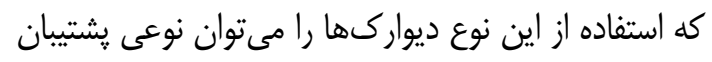

برش، از عمق •^ سانتىمترى نسبت به بـالاترين سـطح

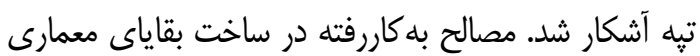

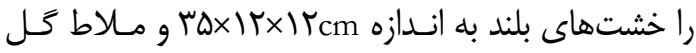

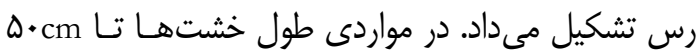

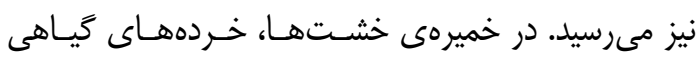

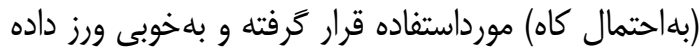

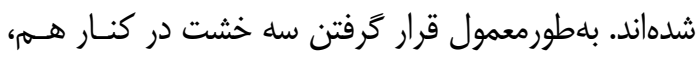

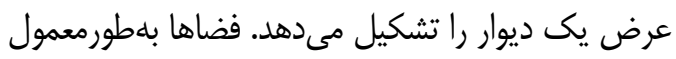

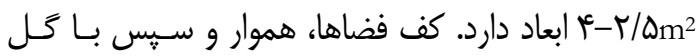

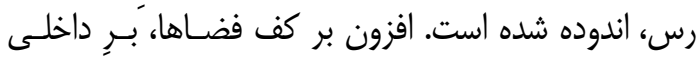

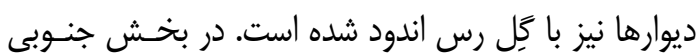

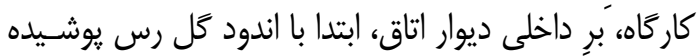

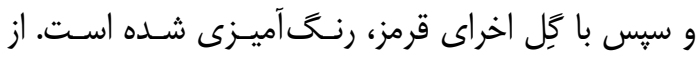

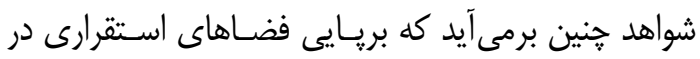
اين مكان، با آكاهى از جغرافيا و اقليم منطقه تصوير ترفته

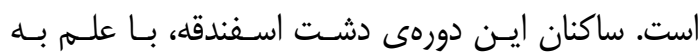

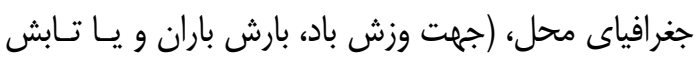

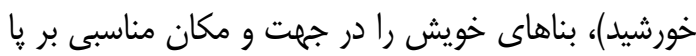

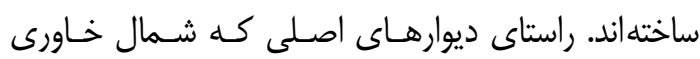

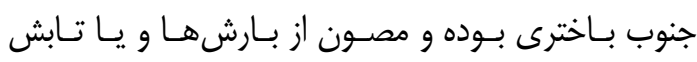

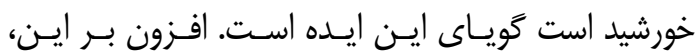

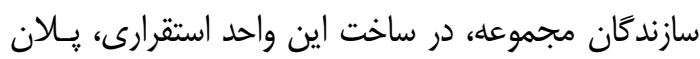

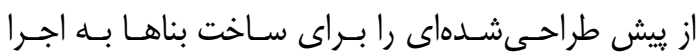

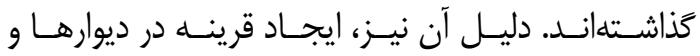

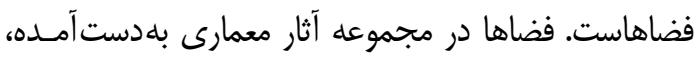




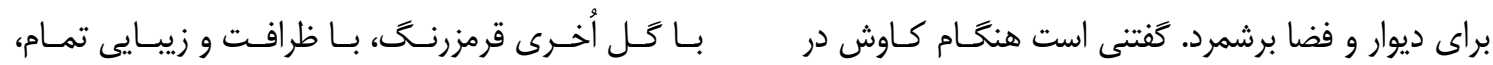

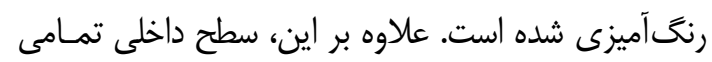

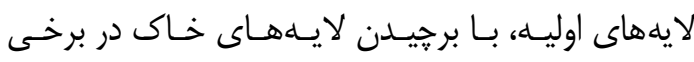

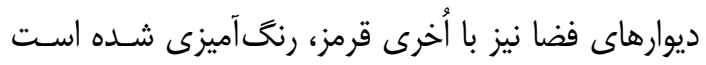

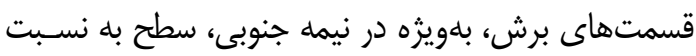

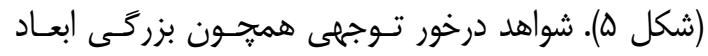

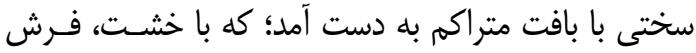

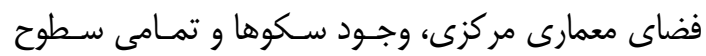

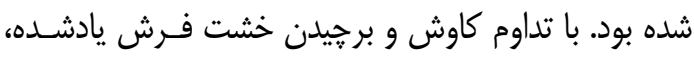

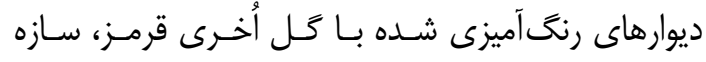
فضاهاى معمارى آشكار شدند.

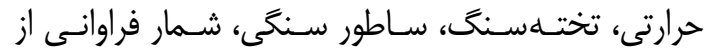

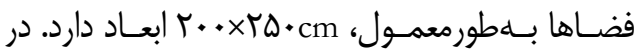

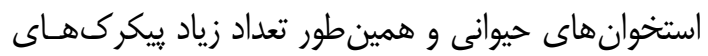

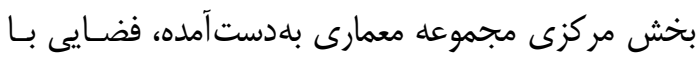

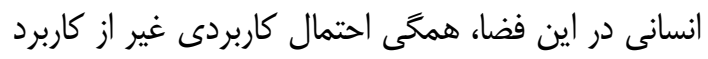

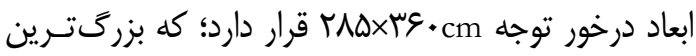

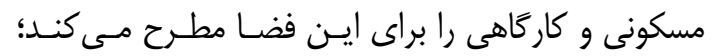

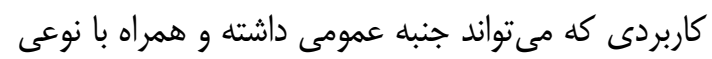

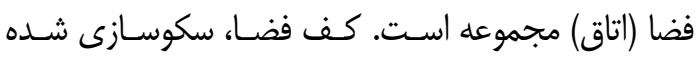

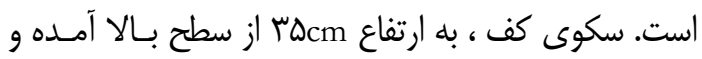

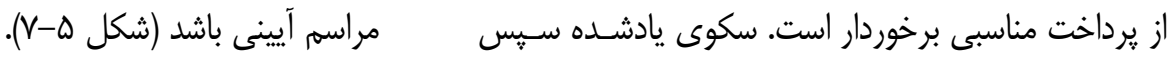

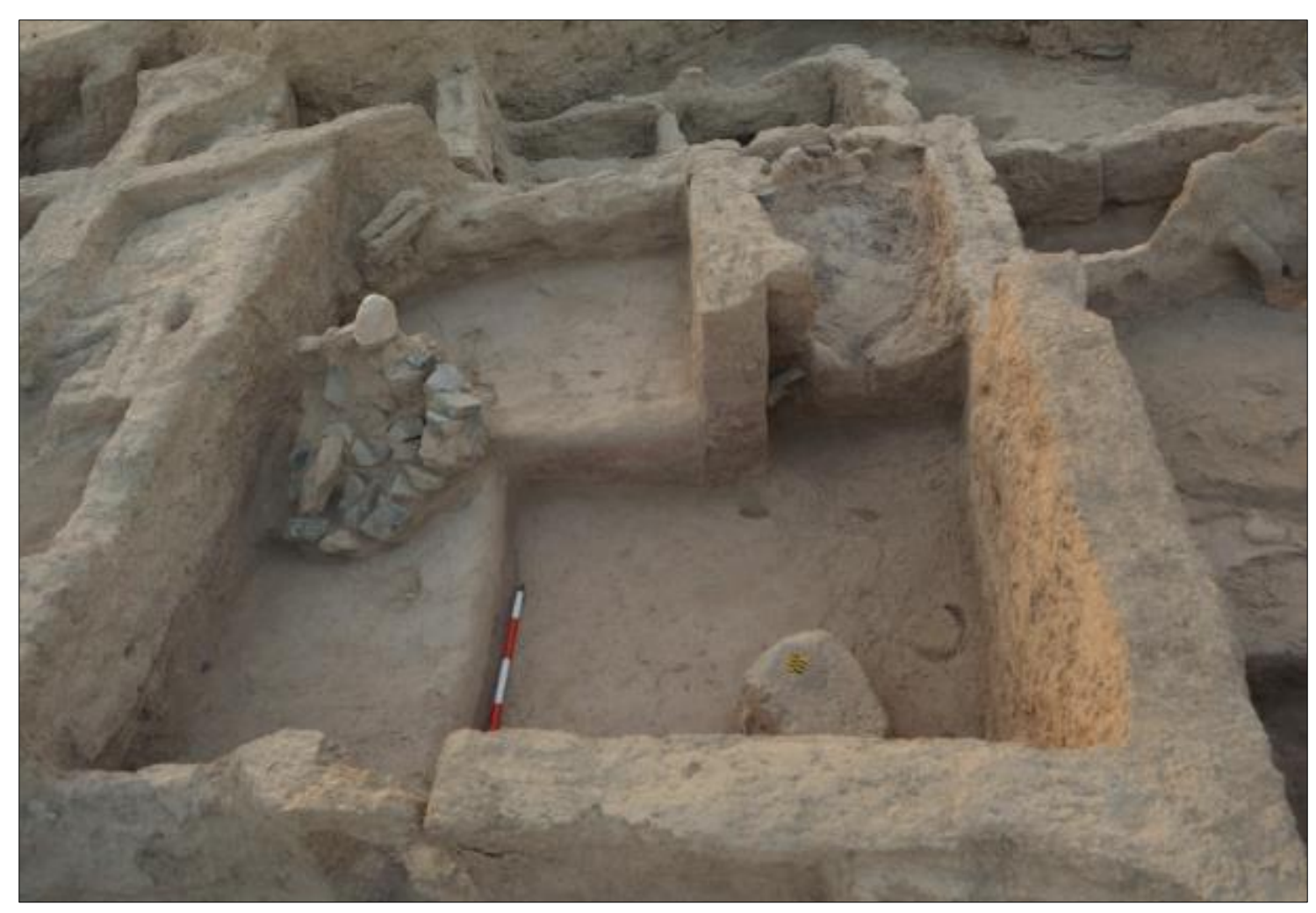

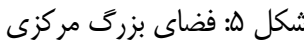

Fig. 5: Large central space 


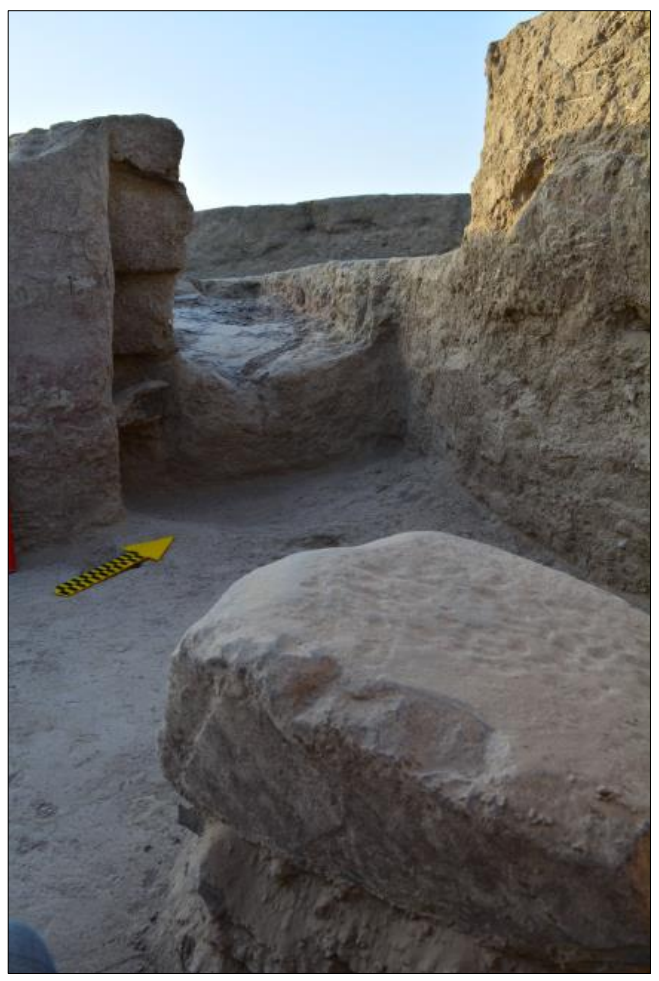

شكل 9: سنخ قربانى؟ و سازه حرارتى :6 ل)

Fig. 6: Victim's stone? And the thermic structure

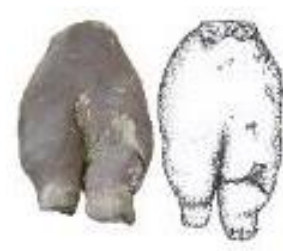

$--$

شكل \: ييكر كهاى بdدست آمده درون فضا

Fig. 7: Figures obtained in space

دوره شكل گيرى كاوكشى ياد مىشود، داراى يخت ناكافى

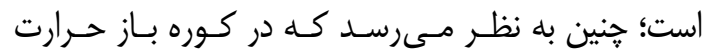

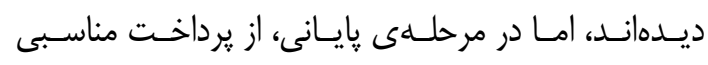

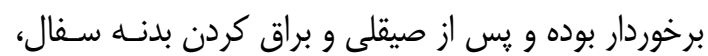
سطح آنها نقشاندازى شده است. خطوط شكسته جناغى

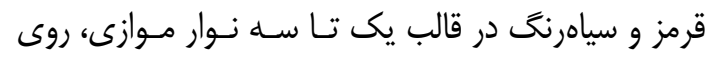

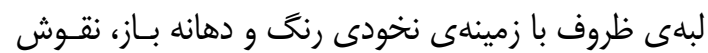

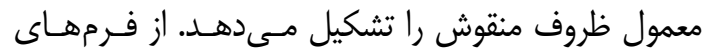

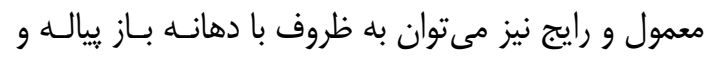
كاسههاى اغلب با بدنه كروى شكل اشاره كرد. سفال فـاز
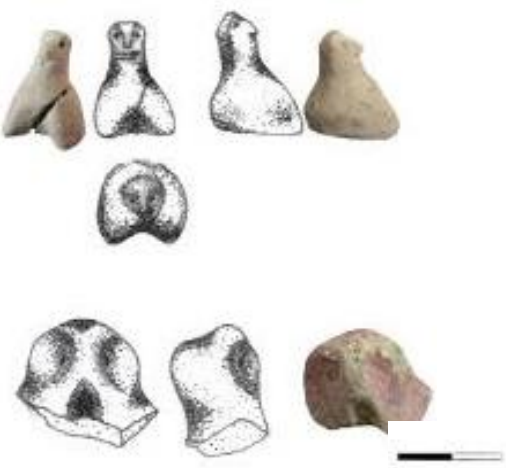

معمــارى ايـنـن دوره (دوره دوم اسـتقرار و نخســــ

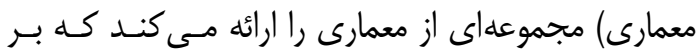

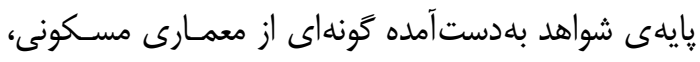
كار كاهى و آيينى را تشكيل مىدهد (شكل ^). سـفال: سـاكنان ايـن دوره، افـزون بــر معمـارى

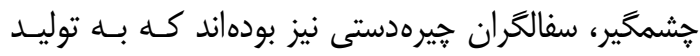
سفال و ابزار سنكى با تكنيك فوق العاده يرداختهاند. سفال بردال اين دوره كه در حال حاضر قديمترين سفال حوزه جنـوب إنسي

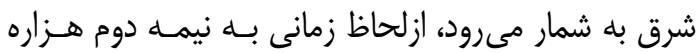

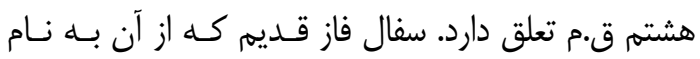




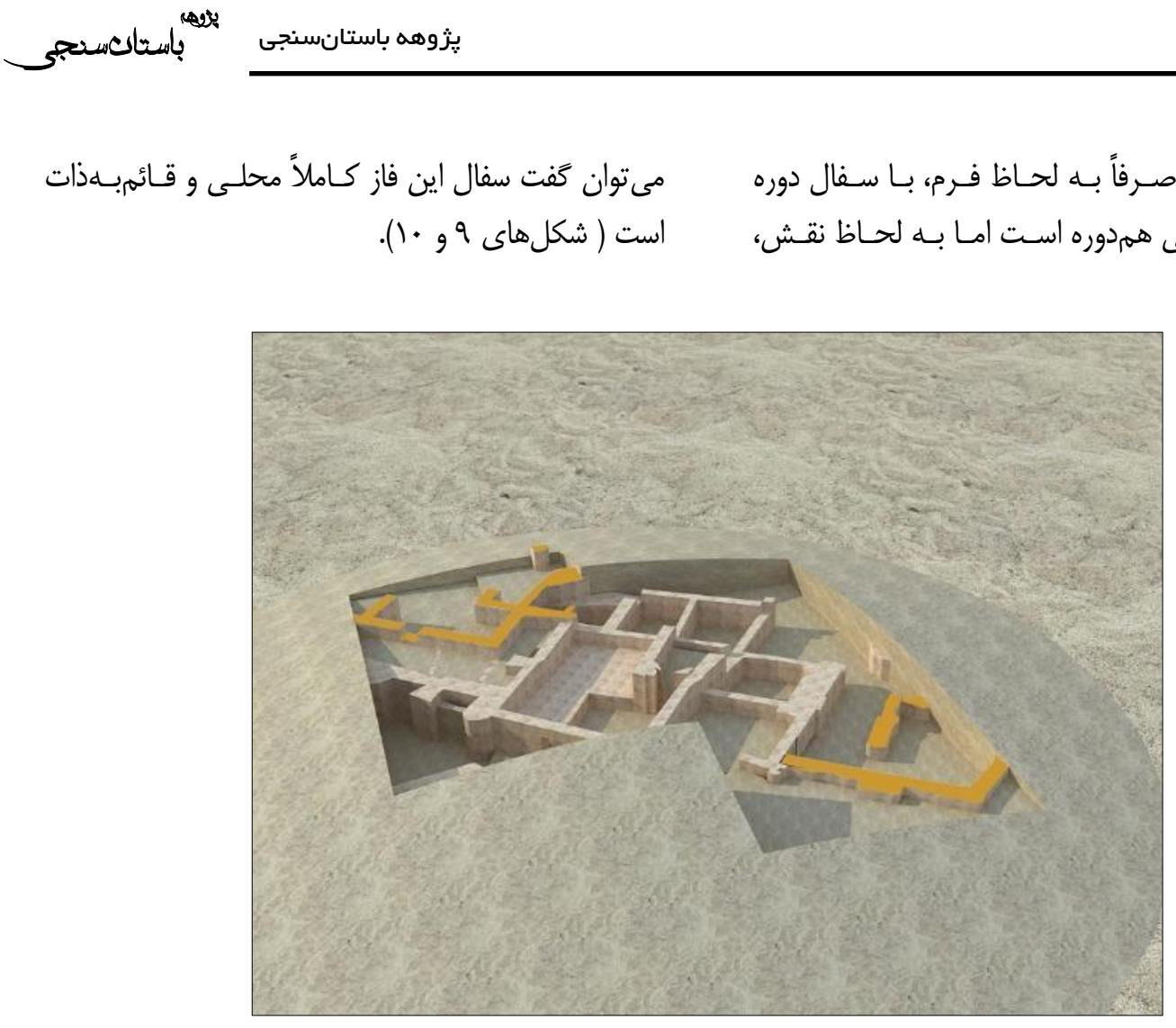

شكل من يلان سلبعدى معمارى تيه گَاوكشى

Fig 8: Architecture 3D Plan of Gav Koshi

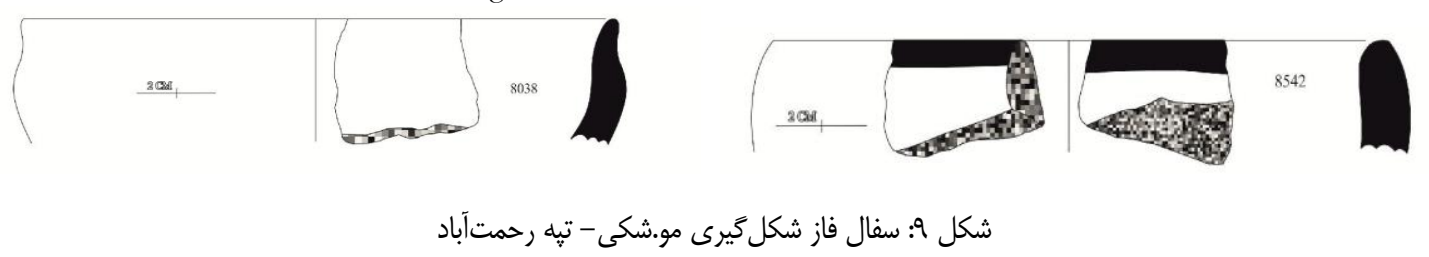

Fig. 9: Pottery of the formation phase of Mushki-Tepe Rahmatabad)
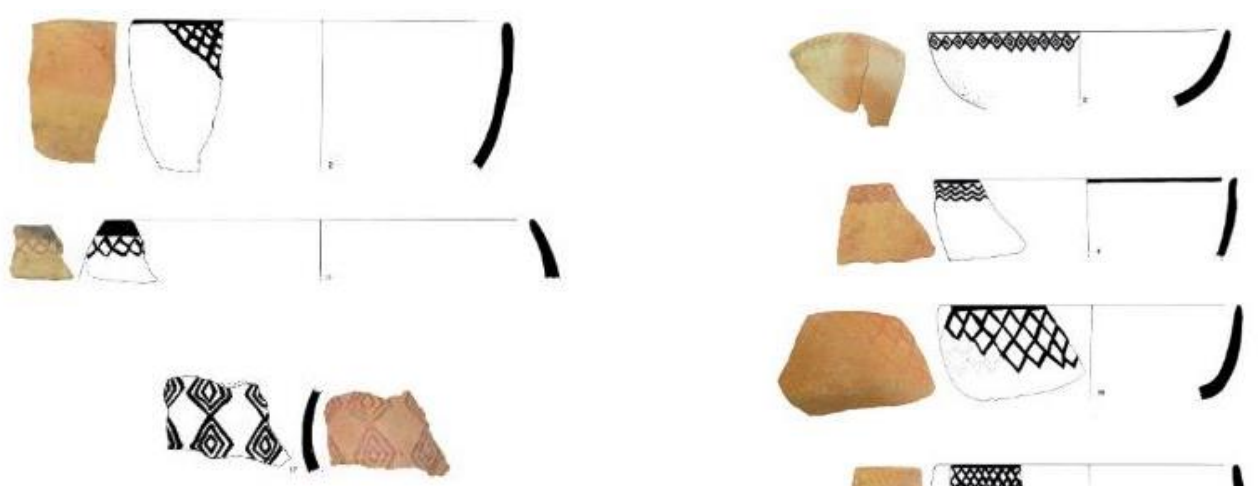

شكل •(: سفال كاو كشى (فاز قديم)

Fig. 10: Gav koshi Pottery (Old Phase)
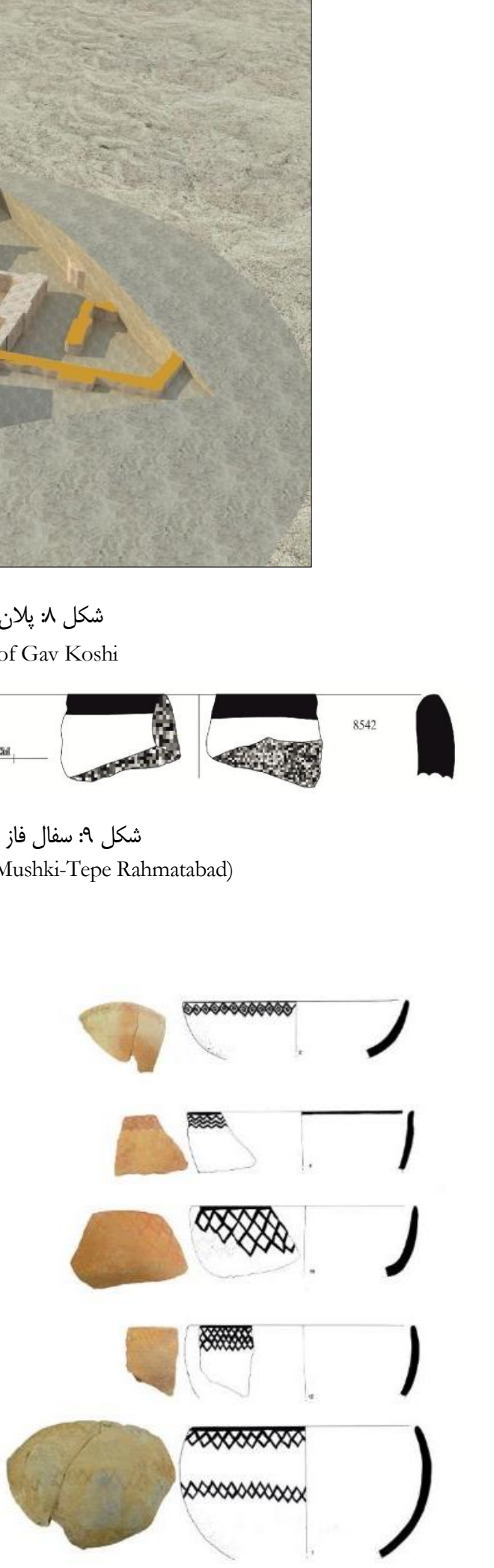

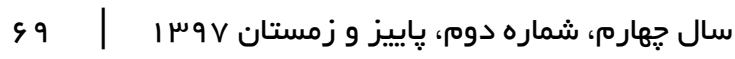


ازجمله ايـن شـباهتهـا، وجـود فضـايى تُندقسـمتى بــاـ ه. فاز دوم (دوره كاوكثى)

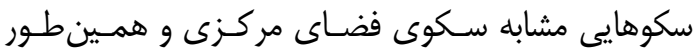

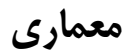

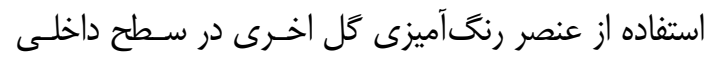

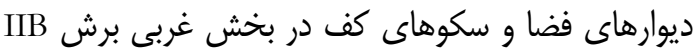

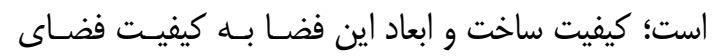

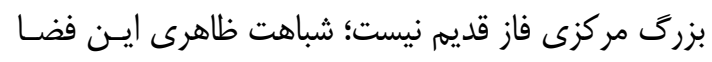

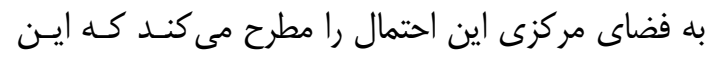

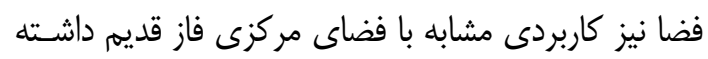

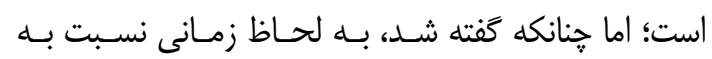
فضاى آيينى مركزى متأخرتر است (شـكل (I) ايـن دوره از معمارى به دوره پايانى استقرار در كاوكشى تعلق دارد.

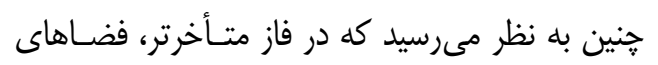

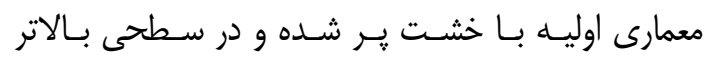
فضاهاى فاز جديد ساخته شدهاند.

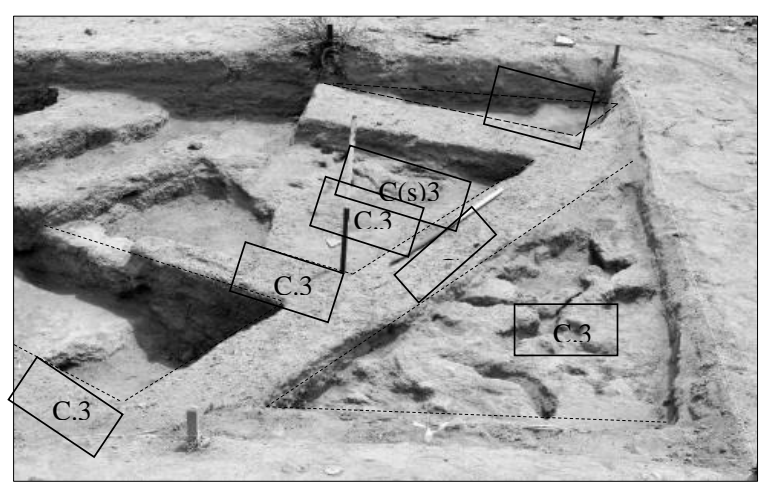

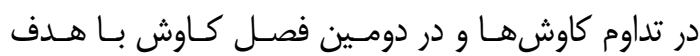

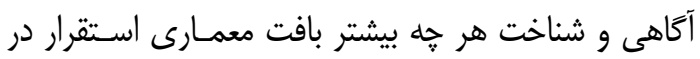

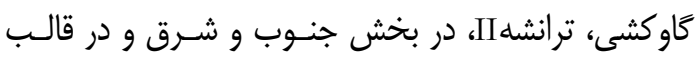

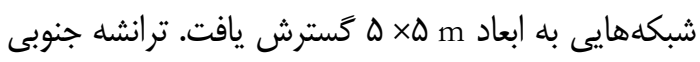

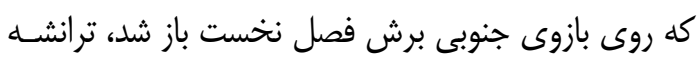

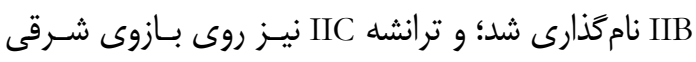

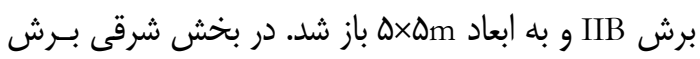

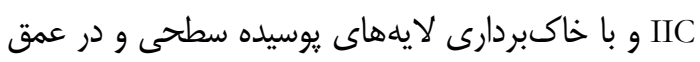

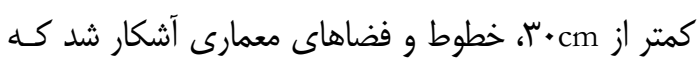

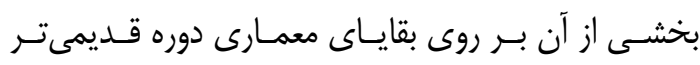

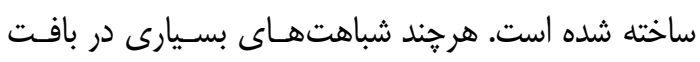

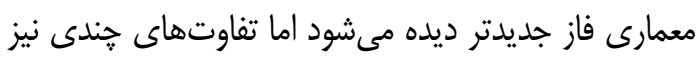

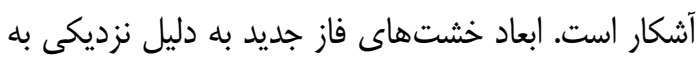
سطح زمين و فرسايش صورت ترفته بر ما معلوم نيست.

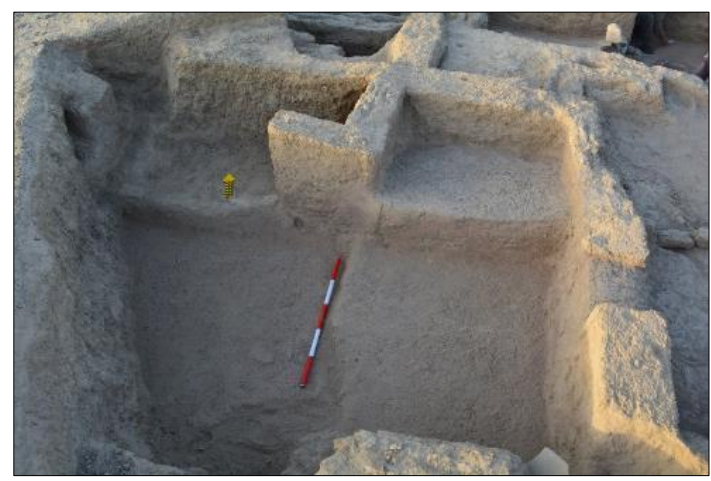

شكل (ا: معمارى كاوكشى (فاز بايانى - كاوكشى III)

Fig. 11: Gav koshi Architecture (Final Phase)

بايانى استقرار، فراوان ديده مىشود. سوم: آرايههاى ير كار،

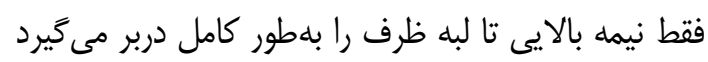

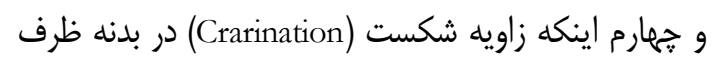

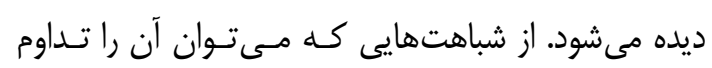

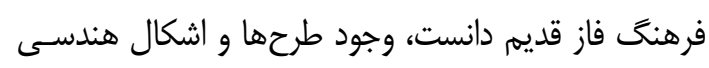

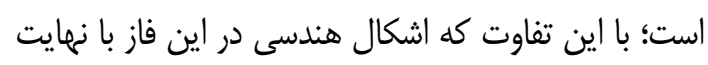

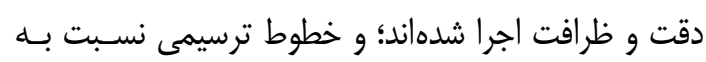
دوره قبل بسيار ظريفتر ديده مىشوند. ظـروف همجنـان

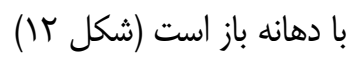

سفال: سفال اين فاز داراى مشابهتها و تفاوتهاى

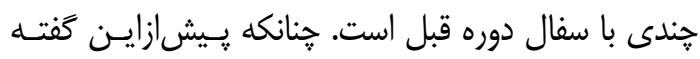

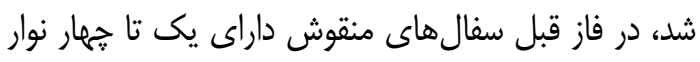

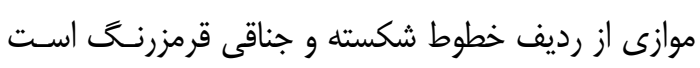

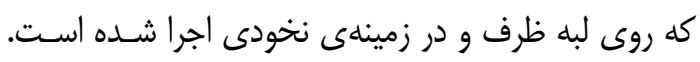

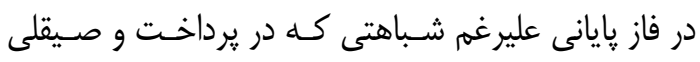

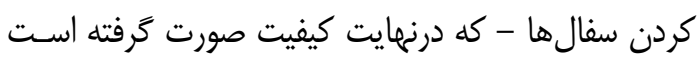
- ديده مى شود، تفاوتهاى اساسى در آرايههاى سفال نيز

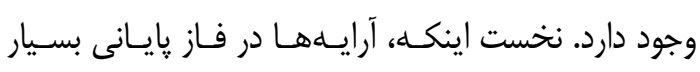
ير كارتر از فاز قديم است. دوم: تنوع نقوش هندسى در فر فـاز

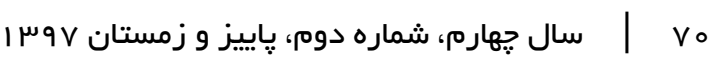




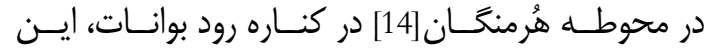

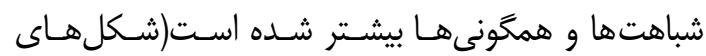

rاgin)

ابزار و ادوات سنكَى: ابزارها اغلب در قالب تيغـه

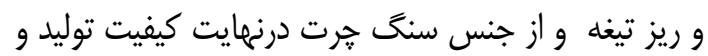

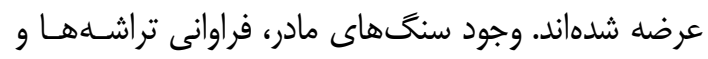

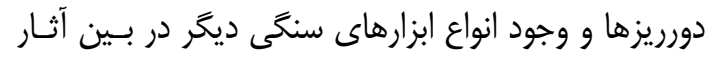

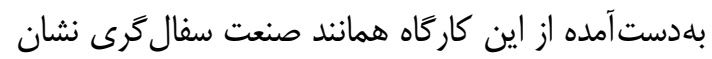
از توليد محلى صنعت ابزارسازى و استفاده از ايـن ابزارهـا

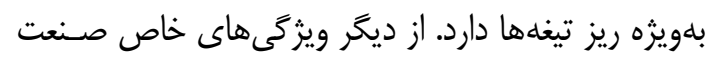

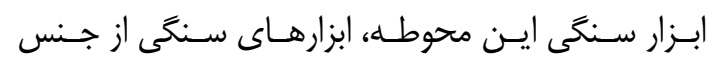

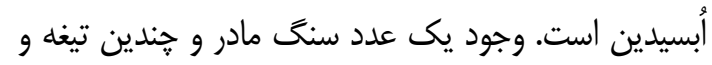

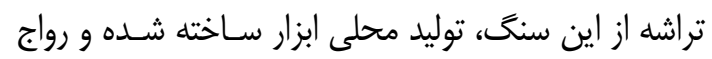

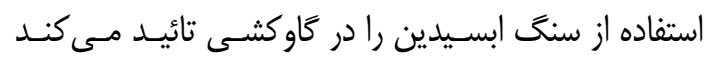

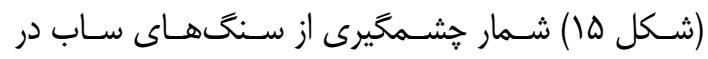

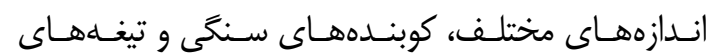

بر קايهى مدارك بلددستآمده از محوطههاى فـارس، اين فرم مشخصه و معمول ظروف دوره نوسـنَى فـارس

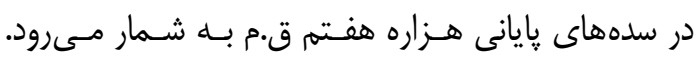

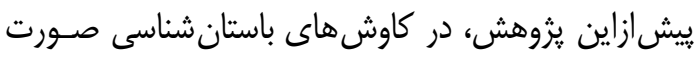

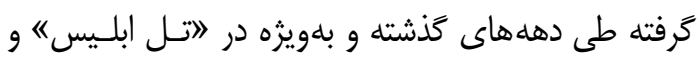
"اتبه يحيى"، از شـباهت نزديـك مـواد فرهنخـى در ادوار

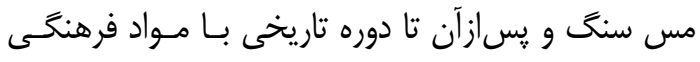
استان فارس در غرب سخن راندهشده بود و اين شباهت و

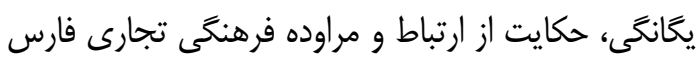

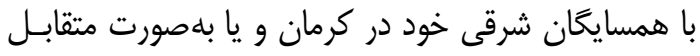

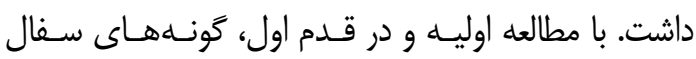

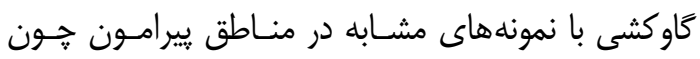

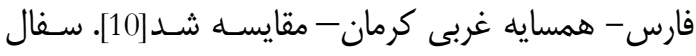

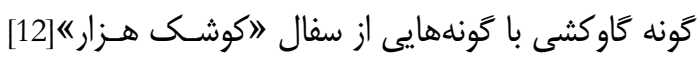

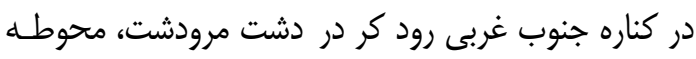

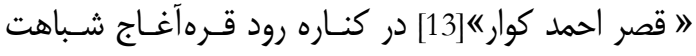

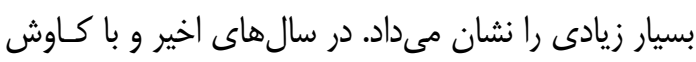

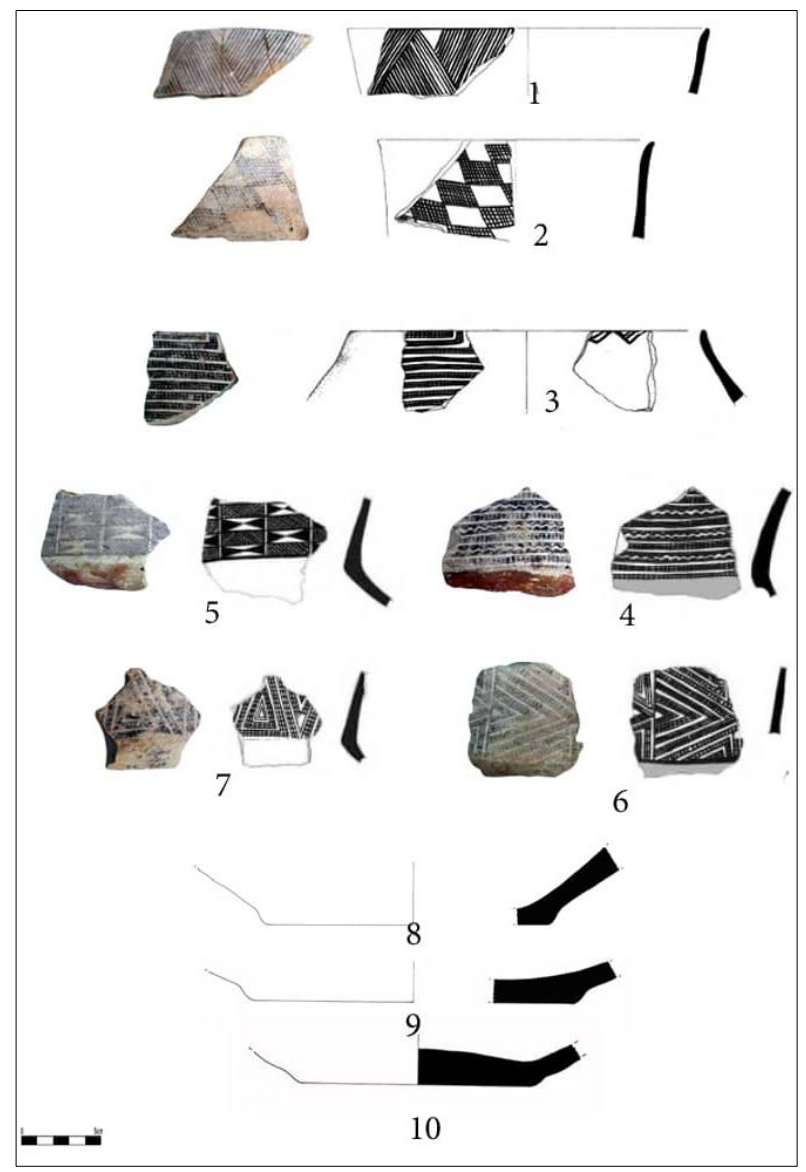

شكل r) أ نمونه سفال فاز نوسنكى بايانى (كاوكشى III) Fig. 12: Samples of the Final Neolithic Phase (Gav koshi II) 


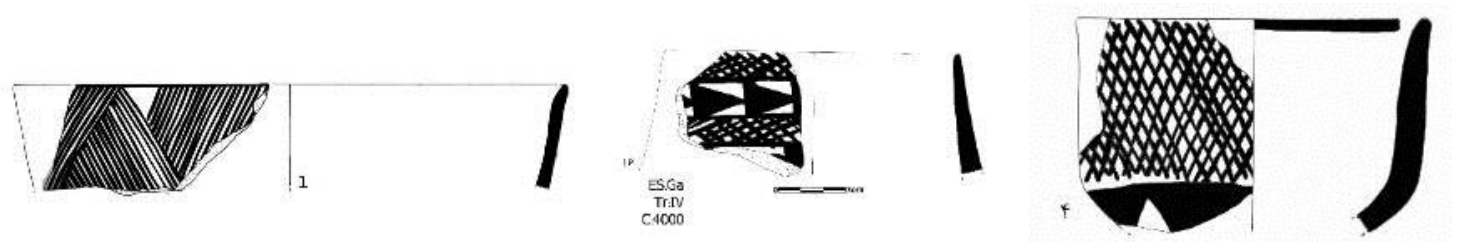

شكل با: سفال كاوكشى

Fig. 13: Gav koshi

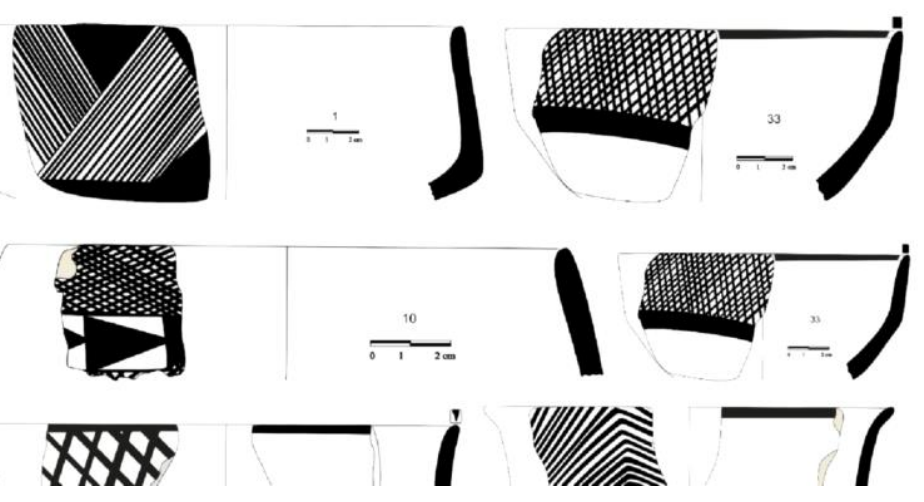

شكل fا: سفال قصر احمد

Fig. 14: Qasr -e Ahmad Pottery
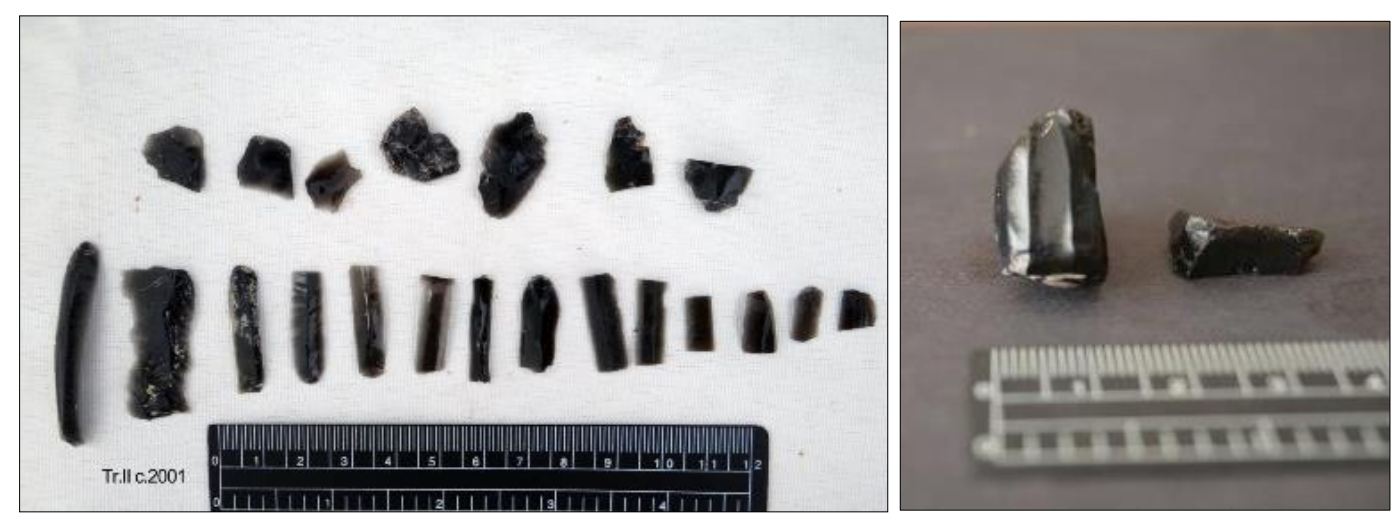

شكل ها: سنگ مادر ، تيغه و تراشه از جنس سنگ ابسيدين - تيه كاوكشى

Fig. 15: Core, blade and flake from obsidian - Tepe Gav koshi

\section{צ. تاريخ كذارى مطلق كَاوكثى

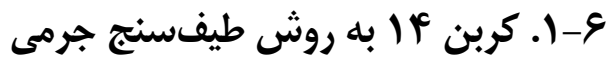 \\ شتابدهنده (AMS)}

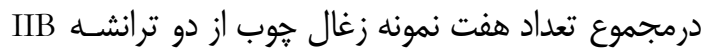

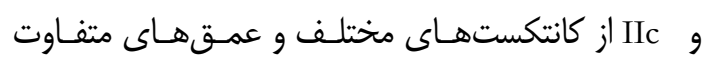
نمونهبردارى شد؛ كه متعلق به فاز قـديم كاوكشى اسـت.

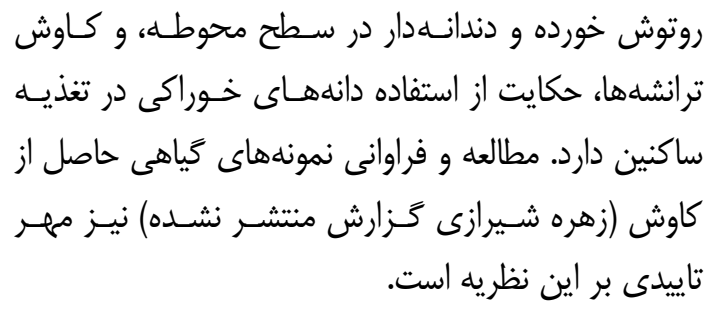

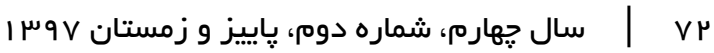




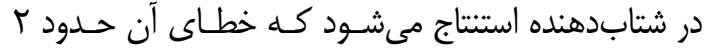
درصد است. ممكن است مقدار $813 C$ اصلى مادمى نمونسه با جداسازى ايزوتوت در طول فرايند جداسـازى يـا توسـط منبع يون شتابدهنده تحريف شود. بنابراين، مقدار فقط براى اصلاح اثرات تجزيه مورداستفاده قرار مى گيرد و

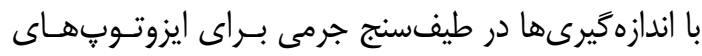

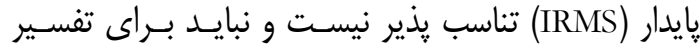
بيشتر يا نشر مورداستفاده قرار كيرد. نتايج بر اساس عمق نمونهها دستهبنـدى مسىشـوند؛ يعنى بايينترين سطح در انتها و بالاترين سطح در بـالاى جدول قرار دارد. هملى نمونهها باهز نمونهى يإيينتسرين سطح، بلهور دقيـق در فاصـلهى زمـانى حسدود . . cal BCE V+ه. با يك ميانهى cal BCE قرار مي ديرند.

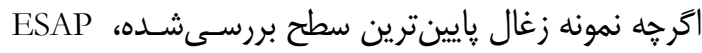
كمى مسـنتر Tr II C; 2015; D: -105/MAMS-27217 به نظر مىرسل، همبوشى قابلتوجهى بين محسدودههـاى

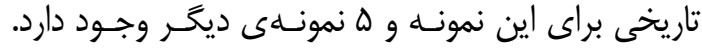
درحالى كه منحنى درجابندى براى تاريخ كربن قـراردادى نداني

دليل آنهم، دسترسى به يـك تـوالى از اسـتقرارهاى تيـهـ كاو كشى بود كه بر اساس بقاياى معمارى حـداقل دو دوره

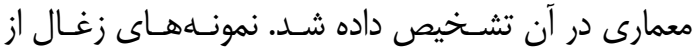

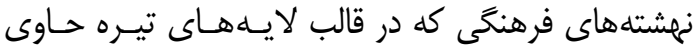
خاكستر و زغال جوب و در مواردى از فراوانسى مناسـبى از زغال برخوردار بودند، انتخاب شد. انتخاب نمونهها، بـدابل دان دخالت دست و با كمجه، درون فويل آلومينيومى قرار داده

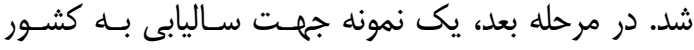
فرانسه و شش نمونهى زغال به مركز كلاوس-تشـيرا در

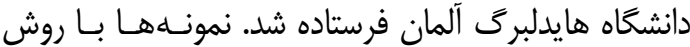
ABA شدند. باقيماندهى غير محلول به روش انجماد خشك شد؛

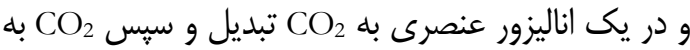

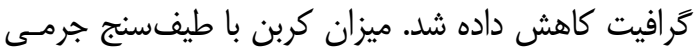
شتابدهندهى MICADAS در مركز كلاوس تشيرا بـراى

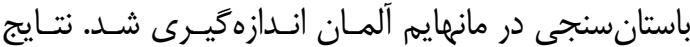
باستانسنجى AMS در جدول (ارائهـ شــده اسـت. بـراى

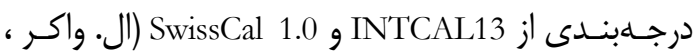

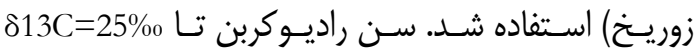

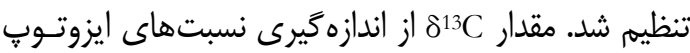
جدول (. تاريخ كذارى مطلق تِّه كَاو كشى (فاز قديم)

Table 1: The absolute date of the Tepe Gav koshi (the old phase)

\begin{tabular}{|c|c|c|c|c|c|c|c|c|}
\hline \multirow[t]{2}{*}{$\begin{array}{l}\text { Sample name } \\
\text { نام نمونه }\end{array}$} & \multirow[t]{2}{*}{ آز آزمايشگاه } & \multirow{2}{*}{$\begin{array}{l}\text { Unmodelled } \\
\text { مدلسازى سال BCE/CE) } \\
\text { (BCEه }\end{array}$} & \multirow{2}{*}{$\begin{array}{c}\text { standard } \\
\text { error } \\
\text { خطاندارد } \\
\pm \\
\pm\end{array}$} & \multirow{2}{*}{$\begin{array}{c}\text { Carbon } \\
\text { cont } \\
\text { ميزبن } \\
\text { C } \\
\\
{[\%]} \\
\end{array}$} & \multirow{2}{*}{$\begin{array}{l}\begin{array}{l}\text { Isotopic } \\
\text { fraction }\end{array} \\
\delta^{13} \mathrm{C}-\text { مقدار } \\
\text { AMS [\%0] }\end{array}$} & \multicolumn{3}{|c|}{ 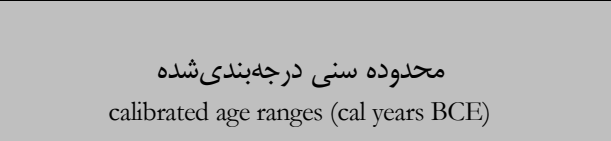 } \\
\hline & & & & & & $\begin{array}{c}\text { فاصله - ( سيخما } 1 \text { (sigma-interval } \\
\text { (68 prop.) }\end{array}$ & $\begin{array}{c}\text { فاصله - } \text { سيخما } \\
\text { 2sigma-interval } \\
\text { (95.4 p prop.) }\end{array}$ & $\begin{array}{l}\text { فاصله س سيخما } \\
\text { 3sigma-interval } \\
\text { (99.7 \% prop.) }\end{array}$ \\
\hline $\begin{array}{l}\text { ESAP Tr II C; 2010; } \\
\text { D: -65 }\end{array}$ & $\begin{array}{l}\text { MAMS- } \\
27218 \\
\end{array}$ & 7951 & 45 & 74,0 & $-27,9$ & -6756 & $7036-6696$ & $7055-$ \\
\hline $\begin{array}{l}\text { ESAP Tr II B; 2015; } \\
\text { D: -70-90 } \\
\end{array}$ & \begin{tabular}{|l|} 
MAMS- \\
27214 \\
\end{tabular} & 7966 & 44 & 63,6 & $-27,3$ & -6815 & $7045-6700$ & $7060-$ \\
\hline $\begin{array}{l}\text { ESAP Tr II B; 2012; } \\
\text { D: -90 }\end{array}$ & \begin{tabular}{|l} 
MAMS- \\
27213
\end{tabular} & 8009 & 44 & 66,1 & $-27,8$ & -6830 & $\begin{array}{|ll|}7066-6714 \\
\end{array}$ & $7083-$ \\
\hline $\begin{array}{l}\text { ESAP Tr II C; 2014; } \\
\text { D: -95 }\end{array}$ & \begin{tabular}{|l} 
MAMS- \\
27215
\end{tabular} & 7971 & 45 & 73,6 & $-29,7$ & -6822 & $7047-6701$ & $7061-$ \\
\hline $\begin{array}{l}\text { ESAP Tr II B; 2016; } \\
\text { D: -100 }\end{array}$ & $\begin{array}{l}\text { MAMS- } \\
27216 \\
\end{array}$ & 7981 & 43 & 66,8 & $-23,5$ & -6827 & $7051-6701$ & $7066-$ \\
\hline $\begin{array}{l}\text { ESAP Tr II C; 2015; } \\
\text { D: -105 }\end{array}$ & $\begin{array}{l}\text { MAMS- } \\
27217 \\
\end{array}$ & 8075 & 45 & 68,6 & $-24,7$ & -6850 & $7178-6828$ & $7308-$ \\
\hline
\end{tabular}

زياد است؛ بنابراين براى اين نمونه، ميانخين محدوده سنى (1)

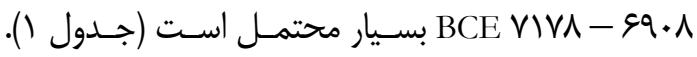

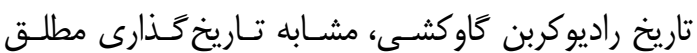

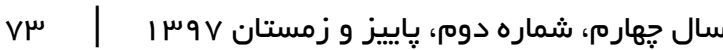

ه نمونهى ديخر تقريباً صـاف و يكسـان اسـت. تجنانكـهـ مىيينيم شيب آن در فاصلهى مربوط به بإيينترين نمونسه نسـتاً ESAP Tr II C; 2015; D: -105/MAMS-27217 
انتخابشده مىبايستى از قدمت بيشترى برخوردار باشـد و

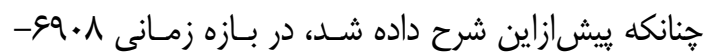

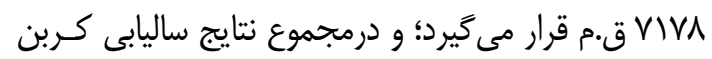

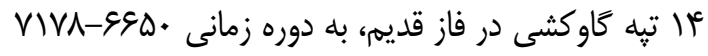

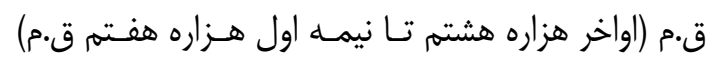
برمى تردد (جدول r).

\section{V}

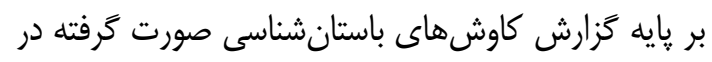

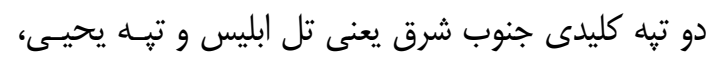

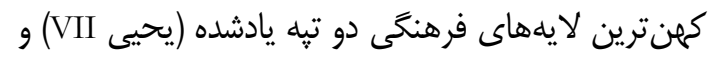

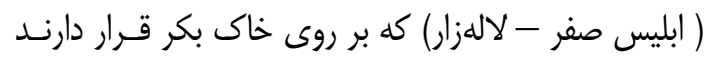

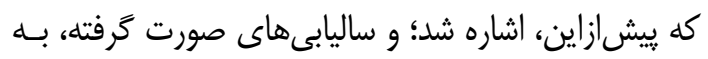

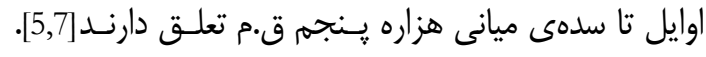

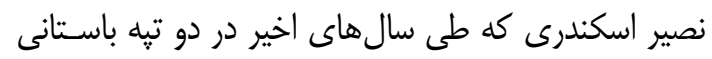

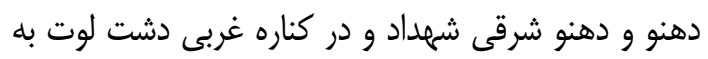

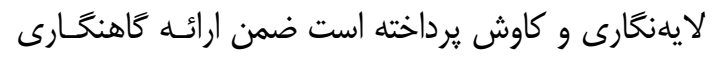

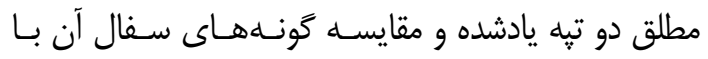
سفال لايههاى مختلف ابليس، نتـايج حاصـل از سـاليابى مانى

\begin{tabular}{|c|c|c|}
\hline $\begin{array}{l}\text { To be use } \\
\text { Stuiver, }\end{array}$ & \multicolumn{2}{|c|}{$\begin{array}{l}\text { Copyright 1986-2013 M Stuiver and PJ Reimer } \\
\text {-To be used in confunction with: } \\
\text { Stuiver, M., and Reimer, P.J., ig93, Radiocarbon, 35, 215-230. } \\
\text { Annotated results (text) - - } \\
\text { Export file - c14res.csv }\end{array}$} \\
\hline \multicolumn{3}{|l|}{$\begin{array}{l}\text { Esf anbdagh } \\
\text { UAB-27759 }\end{array}$} \\
\hline \multicolumn{3}{|c|}{$\begin{array}{l}\text { UBA-27759 } \\
\text { Radiocarbon Age BP } 8022+/-\quad 60\end{array}$} \\
\hline Calibration data se & et: intcal13.14c & \# Reimer et al. 2013 \\
\hline & Cal AD age ranges & $\begin{array}{c}\text { relative area under } \\
\text { probability d1stribution }\end{array}$ \\
\hline 68.3 (1 sigma) & Cal BC $7060-6982$ & 0.389 \\
\hline & 6974- 6910 & 0.319 \\
\hline & 6885- 6829 & 0.292 \\
\hline 95.4 (2 sigma) & cal BC 7081- 6698 & \\
\hline
\end{tabular}

شكل عا:كاليبراسيون تاريخكذارى كربن fا كاوكشى (دوره شكل گيرى گاوكشى)

Fig. 16: 14C dates from Tepe Gav Koshi(Gav koshi Formative)

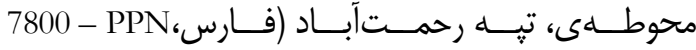
-VD.. ، [15] و 6640 cal BC

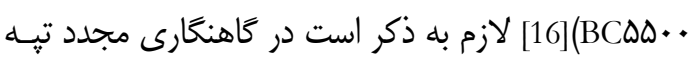
على كش كه توسط دارابى صورت گرفـت، دوره نوسـنـى

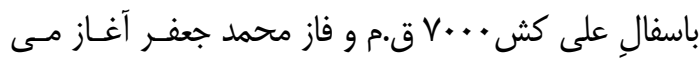

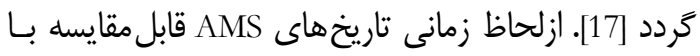
تيه غربى سنَ جخماق در دشت بسـطام اسـت. در ايـن محل، ه سطح معمارى حفارى شد (U-V از بالا به يايين)،

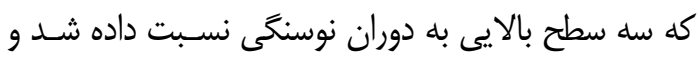

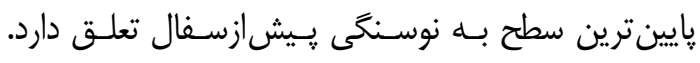

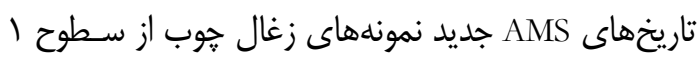

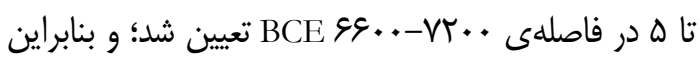
با تاريخهاى جديد از كاوكشى قابل مقايسه هستند. نمونههاى زغال كاوكشى از ترانشه

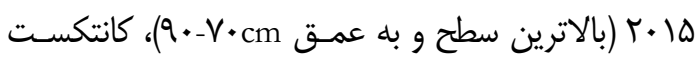

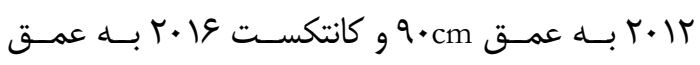

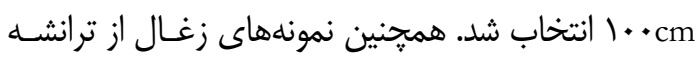

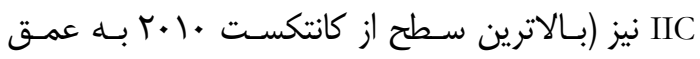
ها $80 \mathrm{~cm}$

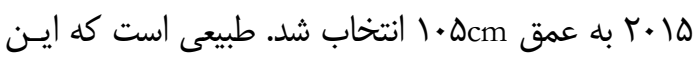

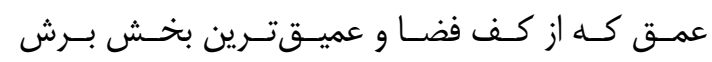

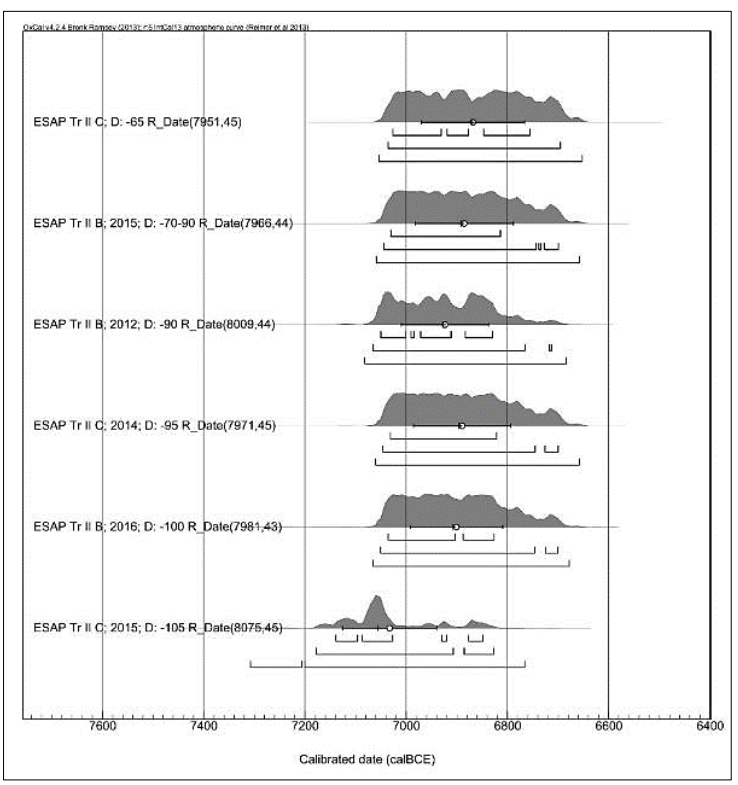

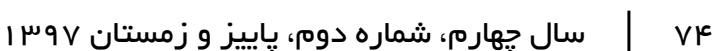


جدول r: گاهنگًارى گاو كشى و محوطه هاى نوسنگى فارس

Table2: Gav Koshi Chronology and Fars Neolithic Sites

\begin{tabular}{|c|c|c|c|c|c|c|}
\hline Date & Archaeological Phase & Gav Koshi & Rahmat Abad & Mushki & Jari & Hormangan \\
\hline 5600 & \multirow{4}{*}{ Jari B } & & \multirow{5}{*}{ Jari } & & \multirow{7}{*}{ Jari } & \\
\hline 5700 & & & & & & \\
\hline 5800 & & & & & & \\
\hline 5900 & & & & & & \\
\hline 6000 & \multirow{5}{*}{$\begin{array}{c}\text { Gav Koshi } \\
\text { Hormangan } \\
\text { Mushki }\end{array}$} & \multirow{5}{*}{ (Phase II) } & & & & \\
\hline & & & \multirow{9}{*}{ Mushki } & & & \\
\hline 6100 & & & & & & \\
\hline 6200 & & & & Mushki & & \\
\hline 6300 & & & & & & New Phase \\
\hline 6400 & \multirow{2}{*}{ Hormangan } & & & & & \\
\hline 6500 & & & & & & Old Phase \\
\hline 6650 & \multirow{5}{*}{$\begin{array}{l}\text { Gav Koshi } \\
\text { Formative }\end{array}$} & \multirow{3}{*}{ Phase I } & & & & \\
\hline 6700 & & & & & & \\
\hline \multirow{2}{*}{$\begin{array}{l}6900 \\
7000 \\
\end{array}$} & & & & & & \\
\hline & & & & & & \\
\hline 7100 & & & Mushk1 Formatıve & & & \\
\hline 7200 & \multirow{3}{*}{ Pre Pottery Neolithic } & & & & & \\
\hline 7300 & & & (Rahmat Abad Phase) & & & \\
\hline 7450 & & & & & & \\
\hline
\end{tabular}

قدمت نيز با آن همزماناند[5,19].

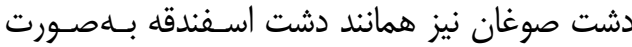
كاسهاى است كه منابع آب ارتفاعات ييرامـون را دريافت مى كند؛ و از اين نظر داراى منابع آب درخور توجهى است. تيه يحيى در بخش جنوبى و دهانه خروجى دشت صوغان

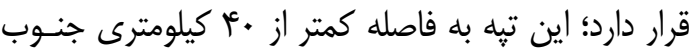

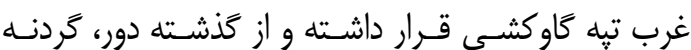
كوهستانى باغ برج، در مراودات تجارى، راه ارتبـاطى بـين

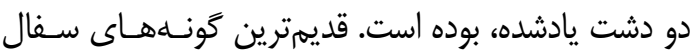

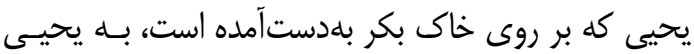

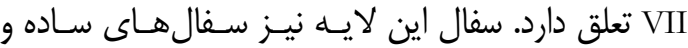
خشنى با خمير قرمز و ناخالصى شن و آميزه كياهى است.

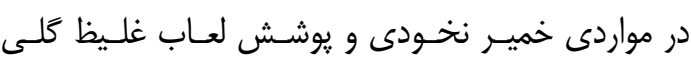
قرمزرنحَ كه نقوش ساده هندسى در بردارد، در اين لايـهـ

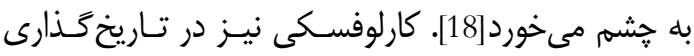

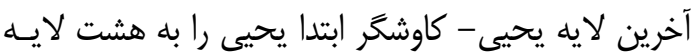

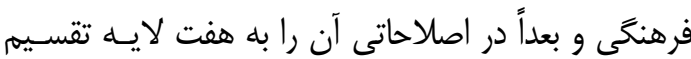

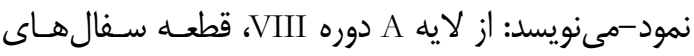

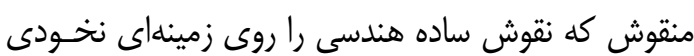

مطلق ارائهشده از اين كاوش، بـــر ايـن اعتقـاد اسـت كـهـ

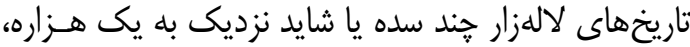

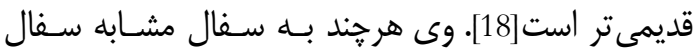

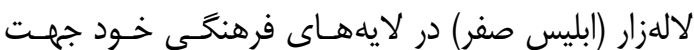
مقايسه، دست نيافته است، امـا بـا فـرض اينكـهـ لايسهى ابليس صفر نيز يك هزاره به عقبتر بركردد، تاريخ ابليس

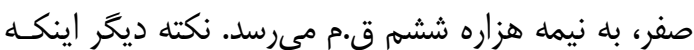

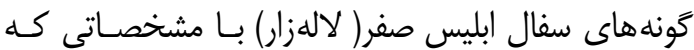
ييش ازاين اشاره شد، شناختهشده اسـت؛ و هـيـيج شـبـاهتى

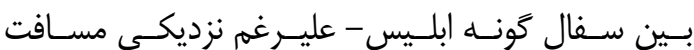
جغرافيايى دو محوطه- با سفال ادوار نوسـنكى نويافتـهـ در

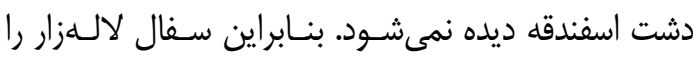

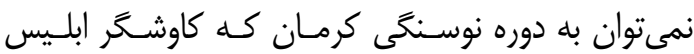
نسبت داده بود تعلق داد. جنانكه در كيفيـت سـفال كَونسه

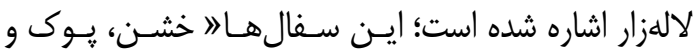

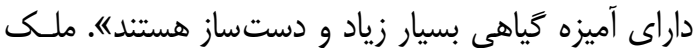
شـميرزادى و زوزف كالـدول بـا برشـمردن خصوصـيات

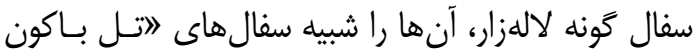
ب" ، واقع در مرودشت فارس دانسته و مىنويسند: ازنظـر 


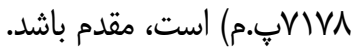

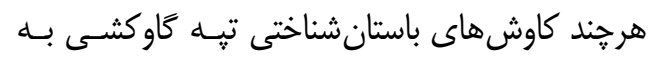

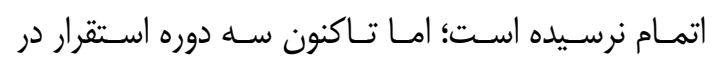

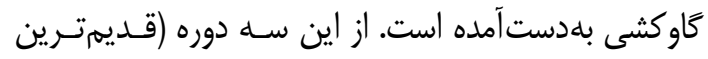

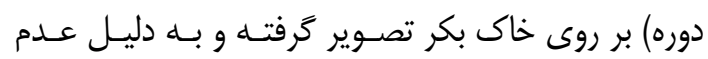

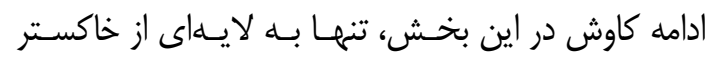

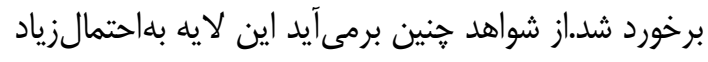

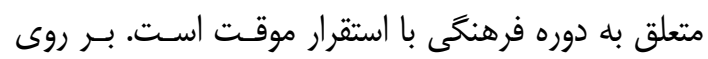

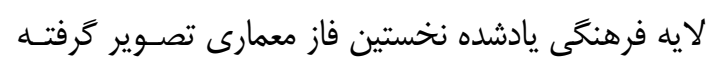

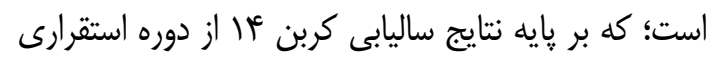
طولانىمدت •هّ سال برخوردار بـوده اسـت. از ايـن دوره

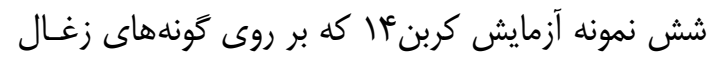

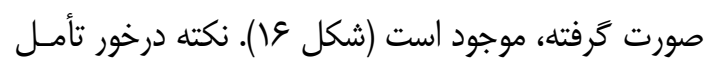

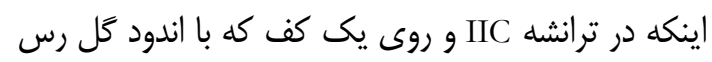

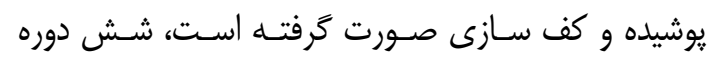

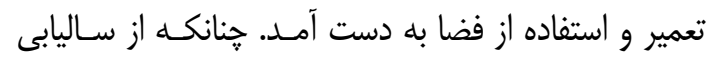

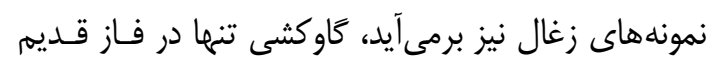

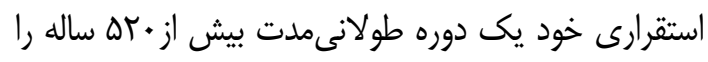

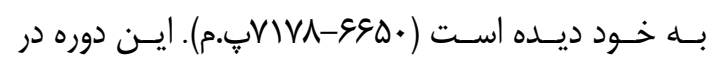

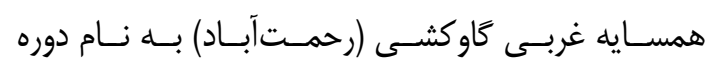

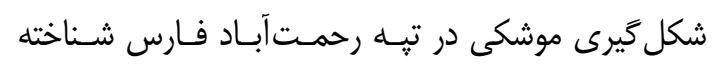

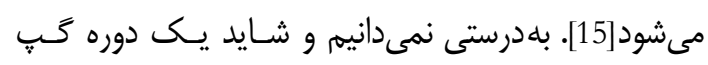

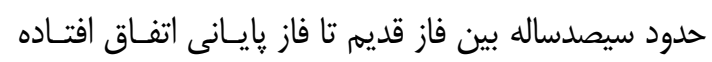
باشد كه منوط به تداوم كاوش در كاوكشى است.

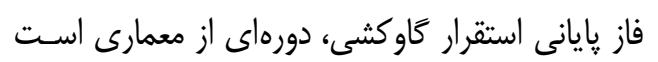
كه بر روى فاز قديمىتر تصـوير ترفتـه اسـت. ايـن دوره

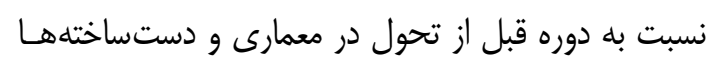

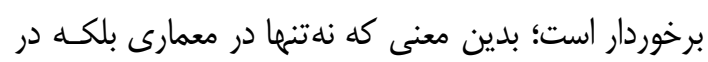

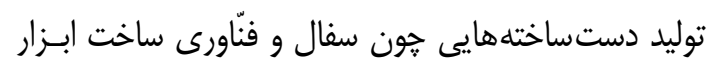
سنكى، نهايت ييشرفت حاصل شده است. سفال اين دوره

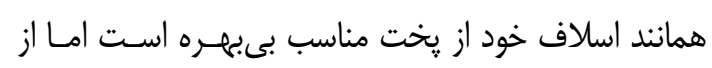

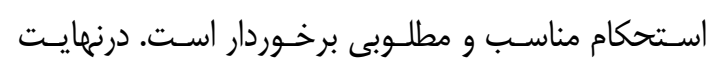

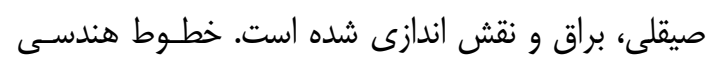

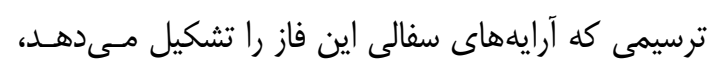

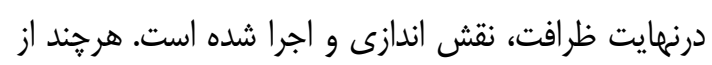

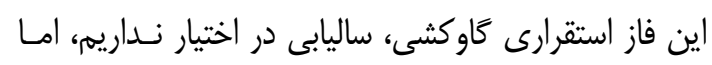

رنح كشيده بودند به دست آمد؛ اين نوع سفالهـا مشـابه

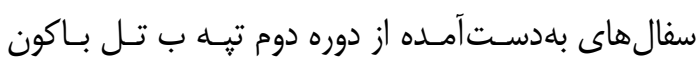
(BII)

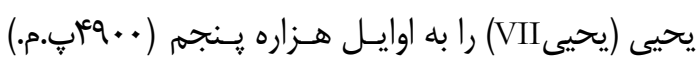

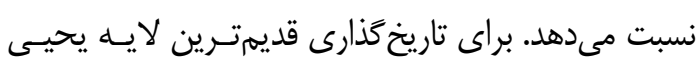

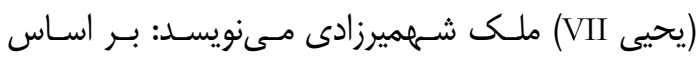

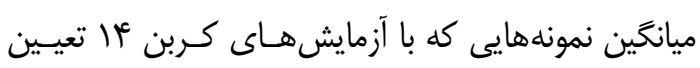

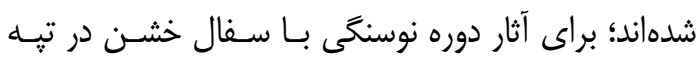

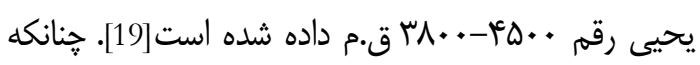

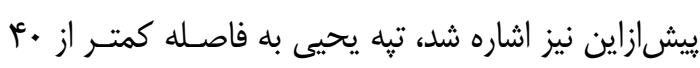

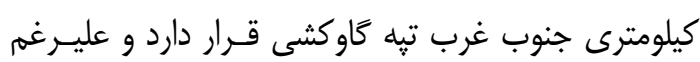

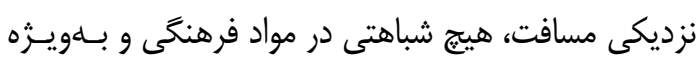
سفال دو تيه در دوره موردنظر ديده نمى شيود.

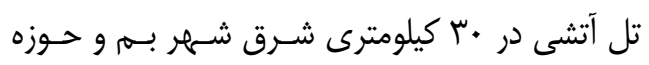

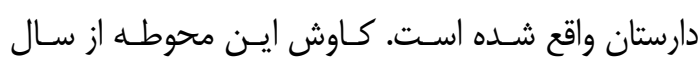

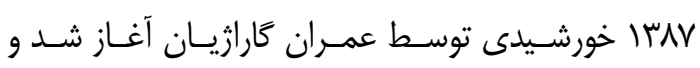

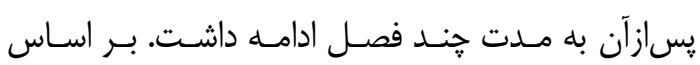

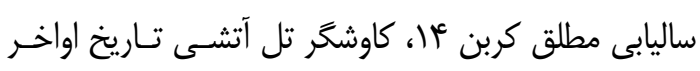

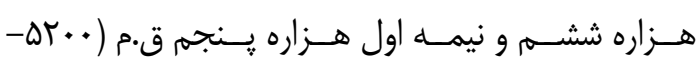
. . عأق.م) را براى فرهنَ آتشى ارائه كـرده و ازآنجاكـه.

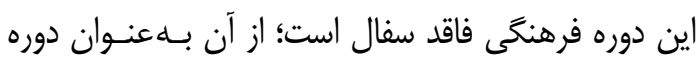

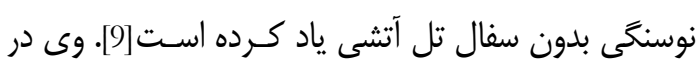

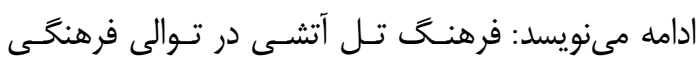

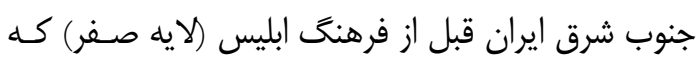

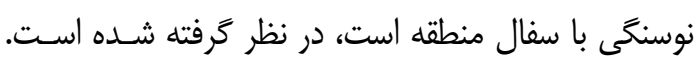

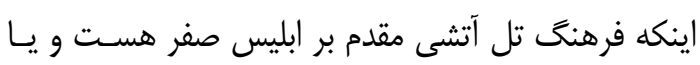

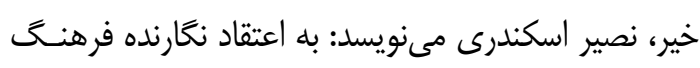

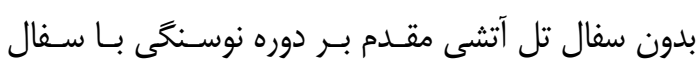

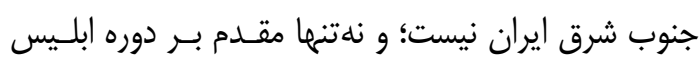

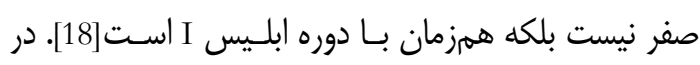

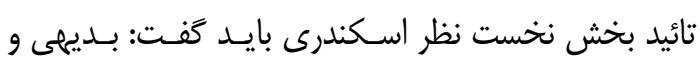

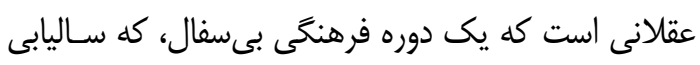

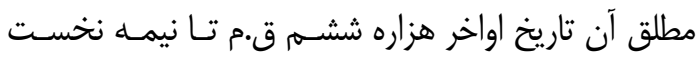

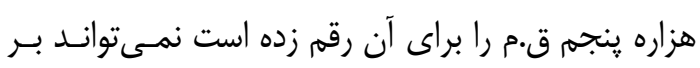

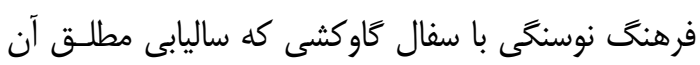

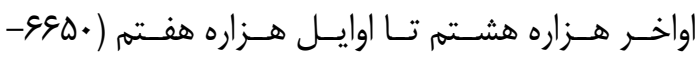


در تكنيك دستافزارهاى سنكى نيز، تفاوتهاى آشـكارى

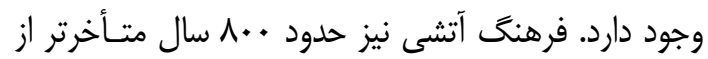

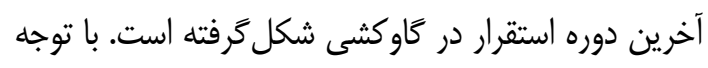

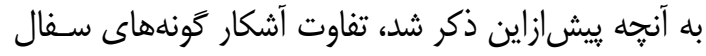

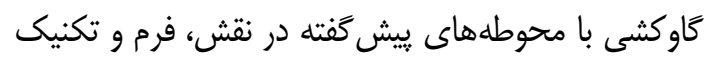

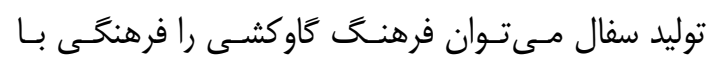

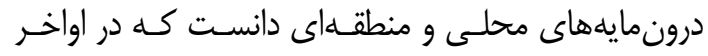

هزاره هشتم ق.م در دشت اسفندقه شكل مَّرفته است.

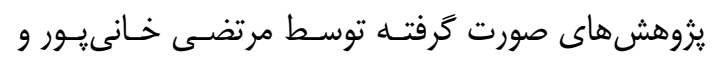

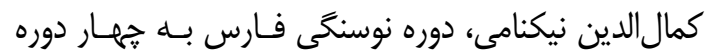

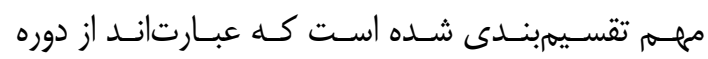

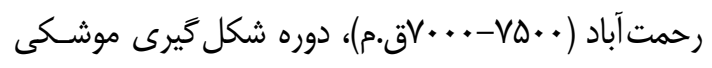

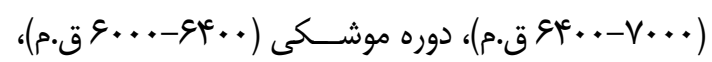

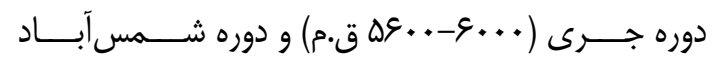

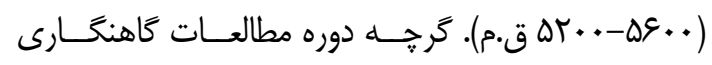

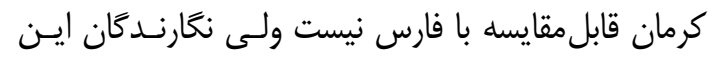

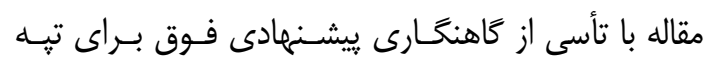

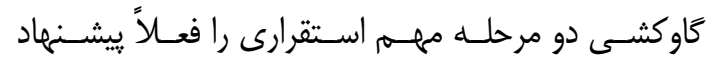

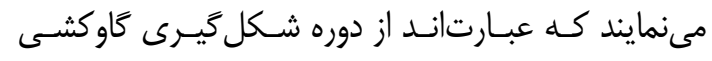

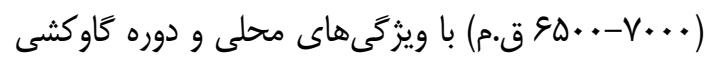

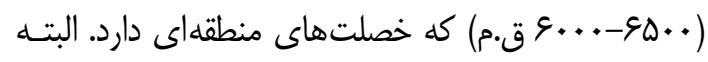
اين را نيز مىدانيم كه تبه گاوكشى داراى وقفه كاهنغارى

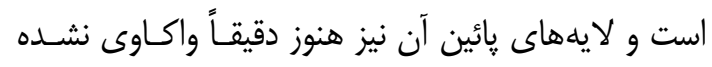

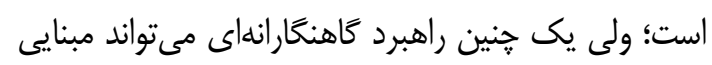
براى مطالعات بعدى باشد.

\section{سباسكَز ارى}

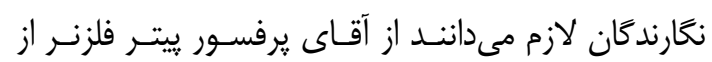

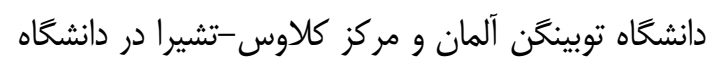

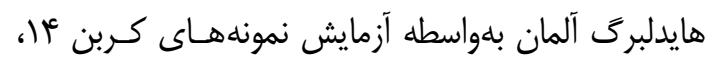

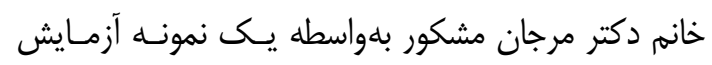
كربن أا در فرانسه، خانم دكتر زهره شيرازى كـه مطالهـ مانه

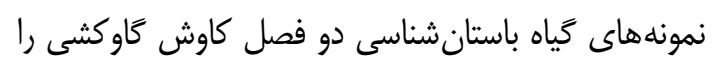
انجام دادند و اعضا تيم كاوش آقايان على دانشى، مرتضى فانى

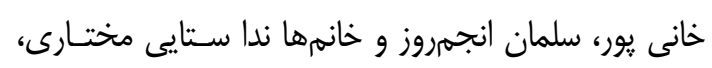

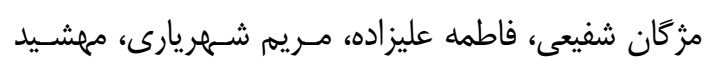

شباهت بسيار نزديكى بين دستساختهها و بهويزه سـفال

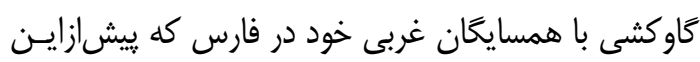

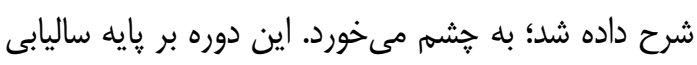

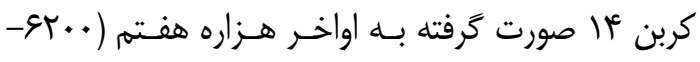

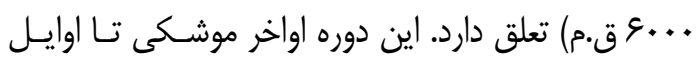

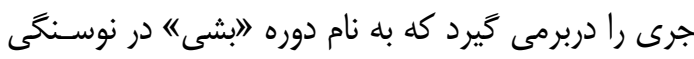
فارس شناختهشده است[15].

\section{1. نتيجهل كيرى}

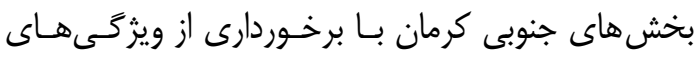

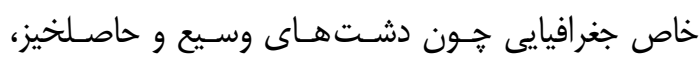

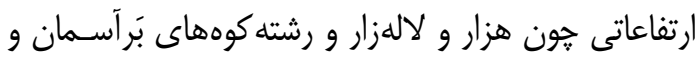

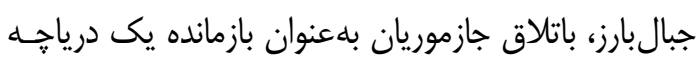

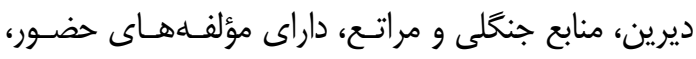

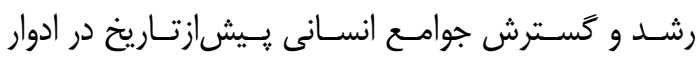

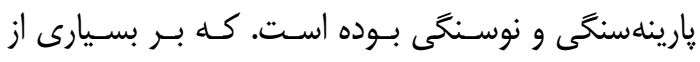

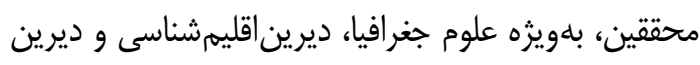

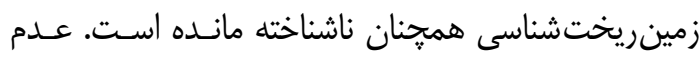

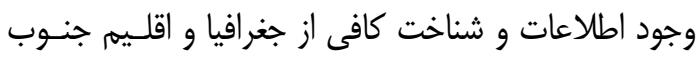

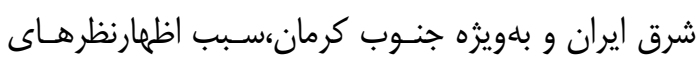

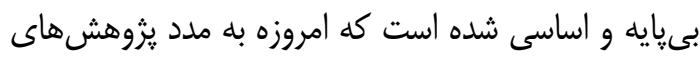

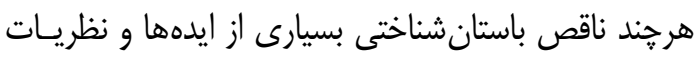

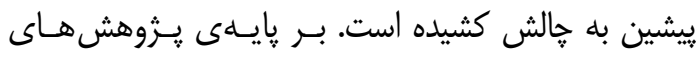

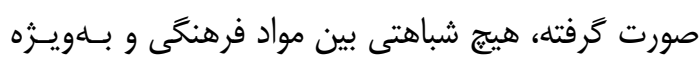

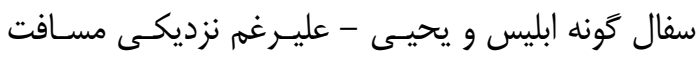

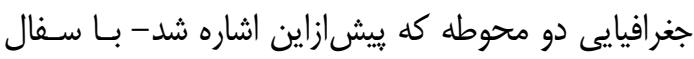

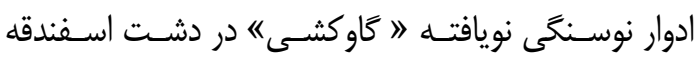

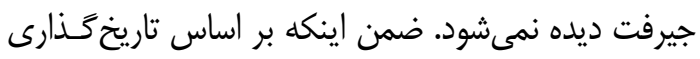

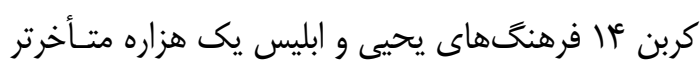

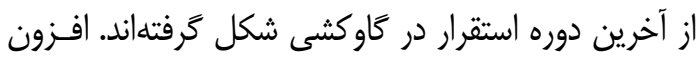

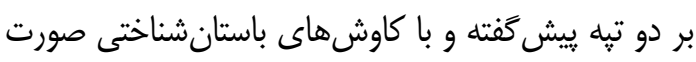

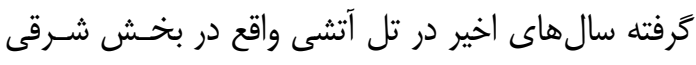

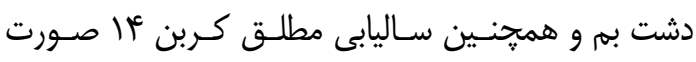

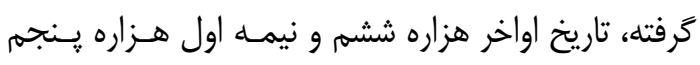

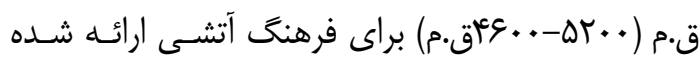

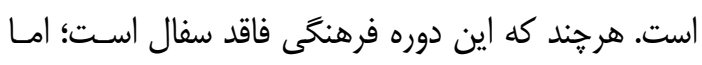




$$
\text { انجام دادند تقدير نمايند. }
$$

\section{References}

[1] Darabi H. Reassessment the Neolithization Process of the Central Zagros: Past Approaches Direction future prospects. Tehran University, 2013. [in Persian]

[دارابى حجت. ارزيابى مجدد فرايند نوسنگى شدان

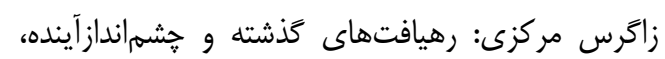

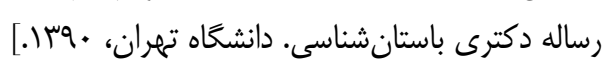

[2] Ajorloo B. The ancient climate of Iran's plateau in the Neolithic Age. Iran Stud 2012;2:1-20. [in Persian]

$$
\begin{aligned}
& \text { [أجورلو بهرام. اقليم ديرين فلات ايران در عصر نوسنكى. }
\end{aligned}
$$

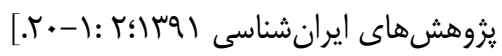

[3] Alidadi Soleimani N. Report of the Fifth season of excavation at Gav koshi Esfandagheh Jiroft. Kerman: 2015. [in Persian]

[عليدادى سليمانى نادر. קنجمين فصل كزارشهاى

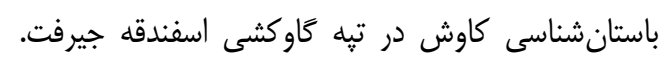

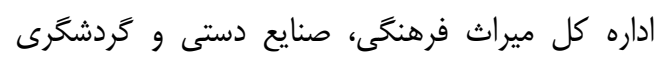

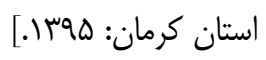

[4] Rafifar j. The popularity of obsidian and its earliest "cultural-technological" exchanges in Iran. J Archeol Hist 1991;5. [in Persian]

$$
\begin{aligned}
& \text { [رفيعفر جلالالدين. رواج ابسيدين و كهنترين تبادلات }
\end{aligned}
$$

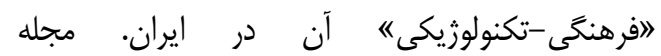

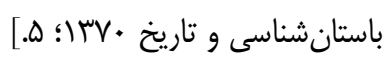

[5] Caldwell JR. Pottery and cultural history on the Iranian Plateau. J Near East Stud 1968;27:178-83.

doi: https://doi.org/10.1086/371962

[6] Priket M. Settlement during the early periods.Excavation at Tepe Yahya, Iran 1967. 1975.

[7] Lamberg-Karlovsky CC, Beale TW, Adovasio J, Heskel D, Mckerrell H, Meadow RH, et al. Excavations at Tepe Yahya, Iran, 1967-1975. The Early Periods. Am Sch Prehist Res Bull 1986.

[8] Mortezayee M. Archaeological Survey and Identificatio in qale Ganj. 2015.

[9] Garazhian O, Rahmati M. Period I of TalieAtashi: Pre-pottery neolithic culture andarchitecture in the landscape of SE Iran. Pazhohesh-Ha- Ye Bastanshenasi

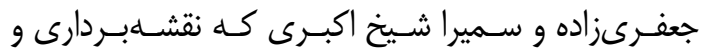

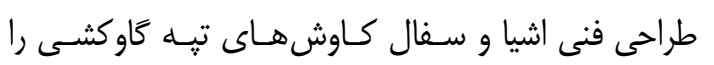

$$
\begin{aligned}
& \text { Iran 2012;2:111-48. [in Persian] } \\
& \text { [كارازيان عمران، رحمتى مسعود. دوره اول تل آتشى، }
\end{aligned}
$$

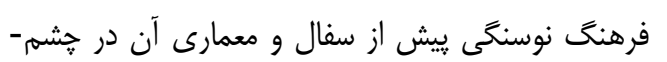

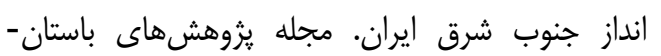

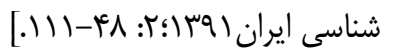

[10] Alidadi Soleimani N. Report of the First season of excavation at Gav koshi Esfandagheh Jiroft. Kerman: 2013. [in Persian]

$$
\begin{aligned}
& \text { [عليدادى سليمانى نادر. بررسى و شناسايى باستانشناسى فئس } \\
& \text { دشت اسفندقه-جيرفت. ميراث فرهنكى استان كرمان: براني }
\end{aligned}
$$

[11] Harris E. Principles of Archaeological Stratigraphy. Samira; 1946.

[12] Alden JR, Abdi K, Azadi A, Biglari F, Heydari S. Kushk-e Hezar: a Mushki/Jari period site in the Kur river basin, Fars, Iran. Iran 2004;42:25-45. doi: https://doi.org/10.2307/4300661

[13] Bernbeck R, Abdi K, Gregg M, Heydari S. A note on the Neolithic of the Qara Aghaj Valley, Fars province. Archaeol Reports 2005;4:27-36.

[14] Khanipour M, Niknami KA. Sequence Chronology Evaluation of the Neolithic Period at Fars on the Basis of Hormangan Site. J Res Archaeom 2017;3:15-29. [in Persian]

فانىيور مرتضى، نيكنامى كمالالدين. ارزيابى توالى

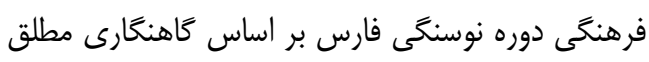

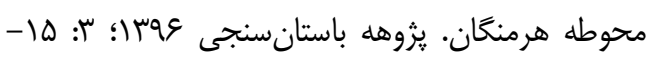

[15] Kharanaghi HA, Nashli HF, Nishiaki Y. Tepe Rahmatabad: A Prepottery and Pottery Neolithic Site in Fars Province. Neolit Iran 2013:108.

[16] Hole F. Revisiting the Neolithic. Iran World Essays Iran Art Archaeol Present to Ezat O Negahban (Tehran 1999) 1999:1327.

[17] Darabi H. Revisiting Stratigraphy of Ali Kosh, Deh Luran Plain. Pazhoheshhaye Bastanshenasi Iran 2018;8:27-42. [in Persian] 
[دارابى حجت. بازنخرى لايهنغارى تبه على كش، دشت

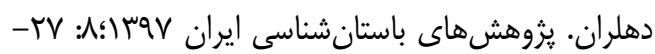

[. Tr

[18] Eskandari N. A Reappraisal of the Chronology of the Chalcolithic Period in SE Iran: Absolute and Relative Chronology of Tepe Dehno and Tepe East Dehno, Shahdad. J Res Archaeom 2018;4:23-35. [in Persian]

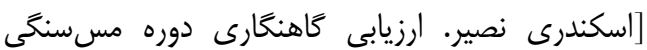

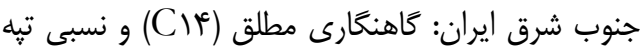

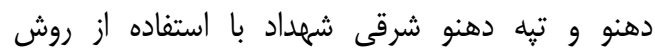

طيفسنج جرمى شتابدهنده (AMS) • يخوها باستان

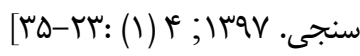

[19] Malek Shahmirzadi S. Iran in prehistory, Iranian archeology from the beginning to the dawn of urbanization. Tehran: Cultural Heritage Organization, Iran; 2003. [in Persian]

[ملك شهميرزادى صادق. ايران در يِيش از تاريخ،

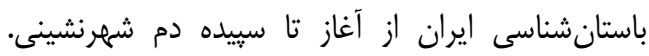

تهران: سازمان ميراث فرهنگى كشور، ايران،برسا]. 